DATA REPOSITORY 2012192 FOR GSA BULLETIN B30598/J. F. HOWLE ET AL.

\title{
AIRBORNE LiDAR DATA
}

The LiDAR data presented in this paper encompasses the Sierra Nevada range front for $33 \mathrm{~km}$ from south of Fallen Leaf Lake near Camp Richardson, California, northnorthwest to the mouth of Ward Creek Canyon southwest of Tahoe City (Fig. 2). The coverage extends from the western shoreline of Lake Tahoe to points 1 to $2 \mathrm{~km}$ west of the eastern escarpment of the Sierra Nevada range front, and covers an area of $131 \mathrm{~km}^{2}$. The LiDAR data was collected in September of 2008 by Towill Surveying Mapping and GIS Services for the United States Army Corp of Engineers (USACE), specifically for characterization of faults of the TSFFZ as part of the USACE Dam Safety Assurance Program for the Martis Creek dam near Truckee, California (Hunter et al., 2011).

Based on the average density of points from fifteen randomly selected 1.84 $\mathrm{km}^{2}$ tiles, the data spot spacing of the laser first returns is approximately $6.0 \pm 0.4$ points $/ \mathrm{m}^{2}$ and the bare-earth point cloud data is $1.6 \pm 0.5$ points $/ \mathrm{m}^{2}$. Towill generated the bare-earth point cloud data (classified ground data) using the software package TerraScan. High-resolution RTK GPS points were collected simultaneously with the airborne LiDAR data for comparison with the classified ground data to assess how well the TerraScan filtering algorithm worked. Thirty control points were collected in open meadow areas (grasses and low shrubs) and an additional 34 points were collected in forested areas with overstory and understory canopies. The average elevation difference for control points in the meadow areas was $0.05 \mathrm{~m}$, while the average elevation difference for control points in the forested areas was $0.20 \mathrm{~m}$. Comparison of all 64 GPS control 
points with the classified bare-earth LiDAR ground points indicates an average difference in elevation ( $\mathrm{z}$ value) of $0.09 \mathrm{~m}$. These differences are similar in magnitude to the positional accuracy (0.1 to $0.2 \mathrm{~m}$ ) of airborne LiDAR returns (Carter et al., 2007). Thus, for the control areas mentioned above, the uncertainties associated with the bare-earth algorithm are indistinguishable from the positional accuracy of airborne LiDAR returns.

We imaged the classified ground data using Quick Terrain (QT) Modeler by Applied Imagery. QT Modeler develops a gridded surface by performing a Delaunay triangulation that mathematically creates a triangulated irregular network (TIN) from the original points. The software then creates the grid according to a user-defined grid spacing (here typically on the order of 1-2 m, except for large-scale maps, where we used a spacing of up to $5 \mathrm{~m}$ ). Elevations from the TIN are then assigned to the vertices of the grid and are re-triangulated to create a smoothed topographic surface. No additional processing was applied to the LiDAR data.

The LiDAR data used in this study was compared with a newer basin-wide LiDAR data set, which was also imaged with QT Modeler. The visual comparison showed little to no difference in the definition of subtle/ incipient fault scarps and hairline ground rupture traces. 


\section{LATE PLEISTOCENE GLACIAL DEPOSITS AND STRATIGRAPHY}

This section provides descriptions of the late Pleistocene 'Tahoe' and 'Tioga' glacial deposits. Previous investigations of the glacial geology in the Lake Tahoe basin (McAllister, 1936; Wahrhaftig and Curtis, 1965; McCaughey, 2003) defined a twofold 'Tahoe' - 'Tioga' sequence at all major canyons from Meeks Creek to Fallen Leaf Lake. In addition to the Tahoe/ Tioga sequence, Birkeland (1964) also identified an older, midPleistocene (?) advance in the Truckee basin that he named 'Donner Lake' (Table 1). Using the high-resolution LiDAR imagery combined with over a decade of field work prior to acquisition of the LiDAR, we have mapped the Quaternary glacial deposits and faults along the west side of Lake Tahoe from south of Fallen Leaf Lake to McKinney Creek on the north. These deposits include the Tioga, Tahoe, and previously unrecognized pre-Tahoe morainal deposits, exposed at the distal ends of the moraine complexes that may correlate to the 'Donner Lake' stage (Figs. DR1, DR2, and DR5).

The succession of Pleistocene outlet glaciers aggraded composite lateral and medial moraine complexes in which the core and volumetric bulk of the morainal complexes consists of pre-Tahoe deposits (Fig. DR1). This relationship is exposed on the south sides of the right-lateral moraines at Fallen Leaf Lake and Meeks Creek, where no subsequent glacial advances have disturbed the older deposits. At these locations, relatively steep-sided Tahoe moraines rest upon a broad buttress of older glacial till (Fig. DR1). The overtopping Tahoe and Tioga moraines were aggraded as inset veneers onto the core of pre-Tahoe deposits. Throughout the eastern Sierra Nevada, as here, Tahoe-age glaciers were thicker than the subsequent Tioga-age glaciers (Blackwelder, 1931; 
Birkeland, 1964; Clark, 1967) so that the stratigraphically older Tahoe moraines are taller and therefore the crests are topographically higher than the Tioga crests (Table 1; Fig. DR1).

Weathering characteristics of Tioga- and Tahoe-age deposits in the Lake Tahoe basin (McAllister, 1936; McCaughey, 2003) have been used to distinguish the younger Tioga moraines by: sharp-crested moraines (3-8 $\mathrm{m}$ wide), competent angular boulders with shallow or nonexistent weathering pans and (in granitic boulders) protruding xenoliths of low relief ( $\sim 2 \mathrm{~cm}$ ), high frequency of surface boulders, steep side-slopes $\left(27^{\circ}\right.$ on average) with minimal development of side-slope gullies, and ash gray soils. In contrast, the Tahoe-age moraines are characterized by broad moraine crests $(5-24 \mathrm{~m}$ wide), friable, rounded boulders with deep weathering pans and (in granitic boulders) xenoliths that protrude $5 \mathrm{~cm}$ or more, a low frequency of surface boulders, less steep side-slopes ( $22^{\circ}$ on average) with enhanced development of side-slope gullies, buffcolored soils, and terminal moraines that have mostly been removed by axial stream erosion.

\section{GEOCHRONOLOGY OF TIOGA AND TAHOE DEPOSITS}

This section describes new terrestrial cosmogenic nuclide (TCN) surface exposure ages for Tioga and Tahoe age moraines at Meeks Creek and an optically stimulated luminescence (OSL) age for a Tahoe moraine at Fallen Leaf Lake.

\section{Terrestrial Cosmogenic Nuclide Surface Exposure Dates at Meeks Creek}

The terrestrial cosmogenic nuclide (TCN) technique relies on cosmogenic nuclides that begin accumulating once a geologic material is exposed near the earth's 
surface. TCN's are products of nuclear reactions induced in target material by secondary cosmic rays. In this study, the target nuclei are $\mathrm{Si}$ and $\mathrm{O}$ in quartz and the product cosmogenic nuclides are ${ }^{26} \mathrm{Al}$ and ${ }^{10} \mathrm{Be}$, respectively. The concentrations of ${ }^{26} \mathrm{Al}$ and ${ }^{10} \mathrm{Be}$ increase over time at an empirically derived production rate. The concentrations can be determined accurately with accelerator mass spectrometry and from these data the exposure age is calculated.

Many factors need to be addressed when sampling and interpreting TCN ages. Factors that may reduce the concentrations of TCNs and cause exposure ages to be younger than the true depositional age include attenuation of the secondary cosmic-ray flux due to snow cover, erosion of the landform (moraine), erosion of the surface of the sampled boulder, and topographic shielding. TCN exposure ages may be older than the true depositional age due to inheritance of TCNs from previous exposure. However, a literature review of TCN-dated boulders concluded that only a small percentage had prior exposure and most published TCN ages are skewed young for the reasons above (Putkonen and Swanson, 2003).

In this study, we have made no corrections for snow cover due to a lack of sitespecific data. However, a deep, long-lasting snow pack on top of the sampled boulders is unlikely, because the boulders are generally elongated, upright, and tall (see below) and would likely have shed accumulating snow. Furthermore, the sampled boulders are situated atop topographically prominent, wind-swept ridges that are exposed to the sun where the snow would readily melt. Despite these mitigating factors, there likely has been some attenuation of the secondary cosmic ray flux that, among other factors, produced exposure ages that are minimum ages (Table DR1). 
Boulders currently exposed on the crest of a moraine may have been buried (shielded) when the moraine was initially deposited. Subsequent erosion of the moraine crest and exhumation of fresh (unexposed) boulders would cause the cosmogenic exposure age to be younger than the true depositional age of the moraine (Zreda et al., 1994; Putkonen and Swanson, 2003). In this study, only prominent moraine-crest boulders ( 2.3 to $4.0 \mathrm{~m}$ tall) were sampled to minimize the shielding effect. The most prominent and upright boulders on the moraine crest should have experienced the least amount of cosmogenic shielding and were expected to produce a representative age distribution (Zreda et al, 1994).

In addition, boulders were assessed for long-term stability by evaluating their overall shape relative to their present position and the orientation of dissolution pockets or weathering pans on older boulders. An oblong boulder sitting in an upright position was considered a good candidate for sampling. Boulders with dissolution pockets on a sloping surface, indicating the boulder has been tilted or rotated, were excluded. The two boulders sampled from the 'Tioga maximum' moraine and the two boulders from the 'Tahoe' moraine are assumed to have been stable based on these criteria (see Fig. DR5 and Table DR2 for sample locations). Flakes 2- to 5-cm thick were chiseled from the tops of the boulders. These flakes were processed and analyzed for ${ }^{10} \mathrm{Be}$ and ${ }^{26} \mathrm{Al}$ concentrations at the Center for Accelerator Mass Spectrometry, Lawrence Livermore National Laboratory. The laboratory methods used are described in Rood et al. (2011).

Exposure-age calculations were made with the CRONUS-Earth online exposure age calculator, version 2.2 (Balco et al., 2008), using a constant production rate model and the scaling scheme for spallation of Lal (1991) and Stone (2000). This version of the 
CRONUS calculator uses a sea level high-latitude (SLHL) reference spallogenic ${ }^{10} \mathrm{Be}$ production rate of 4.6 atoms g- $1 \mathrm{yr}-1$ and a muogenic production of 1.8 atoms g-1 yr-1 after Heisinger et al. (2002a; 2002b). A sample thickness of $5 \mathrm{~cm}$ and no topographic shielding were used in the calculation (Table DR2).

The production rate of cosmogenic nuclides decreases with depth (Gosse and Phillips, 2001), and therefore erosion or spalling of the boulder surface will decrease the exposure age (Lal and Arnold, 1985; Putkonen and Swanson, 2003). We gauged the surface erosion of the boulders that we sampled by measuring the difference in height between protruding mafic xenoliths and the granodioritic core of the boulders (Table DR1). Erosion rates of boulders MC3 and MC4 were calculated using the mean thickness of surface material removed $(21 \mathrm{~mm})$ and the mean zero-erosion-rate age of $20.3 \mathrm{ka}$, which yielded an erosion rate of $1.03 \pm 0.1 \mathrm{~m} / \mathrm{Ma}$. The exposure ages were then recalculated using an erosion rate of $1.0 \mathrm{~m} / \mathrm{Ma}$ (denudation rate in Table DR2). The exposure ages corrected for erosion in Table DR 1 are $\sim 2 \%$ older for the Tioga-age boulders and $\sim 6 \%$ older for the Tahoe-age boulders relative to the ages calculated with a zero-erosion-rate.

As shown in Table DR1, at Meeks Creek, the Tioga maximum moraine (the highest and most extensive of the Tioga lateral moraines) is dated at $20.8 \pm 1.4 \mathrm{ka}$ (boulders MC3 and MC4). Sample MC1 (Tahoe-age) yielded a mean $\left({ }^{10} \mathrm{Be}\right.$ and $\left.{ }^{26} \mathrm{Al}\right)$ exposure age of $46.8 \pm 3.1 \mathrm{ka}$, which falls short of the $64 \mathrm{ka}$ minimum limiting age of MIS 4 (64 -75 ka; Shackleton and Opdyke, 1976) and other published regional age constraints for Tahoe-age moraines (Table 1). Given the significantly older age of MC2 and a marked difference in the height of protruding xenoliths between boulders MC1 and 
MC2, (Table DR1), we conclude that boulder MC1 had a shorter exposure history due to burial and subsequent exhumation, as previously described. Therefore, we have disregarded sample MC1. The MC2 sample for the Tahoe moraine yielded a mean $\left({ }^{10} \mathrm{Be}\right.$ and ${ }^{26} \mathrm{Al}$ ) exposure age of $69.2 \pm 4.8 \mathrm{ka}$, which falls within the limiting ages of MIS 4 and other published regional age constraints (Table 1).

\section{Optically Stimulated Luminescence Age Date at Fallen Leaf Lake}

The following paragraph is excerpted from Berger et al. (2009). Optically stimulated luminescence (OSL) dating determines the time since last exposure to daylight of feldspar and/or quartz grains in unheated sediments. This provides a unique dating tool for Quaternary sediments. OSL is highly sensitive to daylight, with as much as $90 \%$ of the quartz signal removed in only 5-15 seconds of full sunlight exposure (Godfrey-Smith et al., 1988). The effectiveness of this removal ("optical bleaching" or "zeroing") in natural settings depends on several factors, including the ambient spectrum of light and the duration of the light exposure (Berger, 1990). For example, single grains transported in fluvial systems are not always exposed to full sunlight, and if transport occurs in darkness they are not exposed at all. After burial of quartz and feldspar grains, low-level, ambient ionizing radiation (mainly from decay of $\mathrm{K}, \mathrm{U}$, and Th isotopes) provides an effectively constant dose rate $\left(D_{R}\right)$ to the buried crystals. This ionizing radiation dislodges electrons from lattice sites into lattice traps, some of which may be stable over more than a million years. Photonic stimulation in the laboratory (OSL) induces a fraction of the trapped light-sensitive charges to release photons. The intensity of the OSL is proportional to the time since last daylight exposure (time since burial). This OSL 
is scaled with calibrated radiation sources to yield a paleodose $\mathrm{D}_{\mathrm{E}}$ (or "equivalent dose"), the total energy from ionizing radiation that has been stored in the crystal since the last daylight exposure. $D_{R}$ is the annual rate of storage of ionizing-radiation energy in the crystal. The burial age $t=D_{E} / D_{R}$, in calendar years. With careful laboratory procedures and several corrections, a dating precision of $10 \%$ or better can be attained routinely with multigrain single-aliquot regenerative dose (SAR) quartz methods (e.g., Murray and Olley, 2002; Murray and Wintle, 2000, 2003).

Two samples of a silty lacustrine deposit exposed a meter beneath till in the Tahoe maximum terminal moraine at Taylor Creek (see Fig. DR1 for sample location) were collected by G.W. Berger and R.A. Schweickert. While shielded beneath a lightproof tarp, the surface layer of the outcrop was removed, and then light-tight thin-wall tins were driven into the outcrop and promptly capped.

Preliminary results from a multigrain SAR analysis produced an age of $73.2 \pm 8.7$ ka (G. W. Berger, written communication to R.A. Schweickert, 2011). We interpret this result to represent a maximum age for the overlying Tahoe maximum terminal moraine.

\section{EMERALD BAY BATHYMETRIC DATA}

High-resolution ( $0.6 \mathrm{~m}$ grid spacing), multi-beam bathymetry of Emerald Bay was collected in September, 2009, using a R2 Sonic 2024 Broadband Multibeam Echosounder. For each ping there were 256 beams with a beam width (opening angle) of 0.5 degrees across track and 1.0 degrees along track. Data were logged at a frequency of $280 \mathrm{KHz}$ in shallower water, with a swath width of 110 degrees, and $200 \mathrm{KHz}$ in deeper 
water, using a swath width of 90 degrees. The overlapping swaths generated a data set with $200 \%$ coverage. A POS MV 320 version 4.0 positioning and orientation system was used for horizontal positioning of sonar data, to correct for vessel orientation (i.e. heave, pitch, roll, and heading), and to provide precise timing to the data collection computer. The positioning data from the POS MV was corrected for GPS errors using a CSI MBX2 Differential Beacon Receiver receiving corrections from a U.S. Coast Guard Station located in Lincoln, California. An Odom Digibar Pro Sound Velocity Profiler was used to correct for speed of sound variations in the water column, while an AML Smart SV was used to monitor lake surface sound velocity in real time for the R2 Sonic 2024 Beam former. Lake stage data recorded by the U. S. Geological Survey was used to convert recorded depth data to a 1988 North American Vertical Datum (NAVD88) elevation. Data were collected with QPS QINSY version 8.0 software and processed using QPS QLOUD 3D visualization program. QT Modeler, described above, was used to create the bathymetric (topographic) surface and to merge the bathymetry with the airborne LiDAR data.

\section{MATHEMATICAL MODELING OF PLANES AND VECTORS}

At thirteen locations in the study area, piercing-line vectors on both sides of a fault have been mathematically defined by the intersection of best-fit planes to the side slopes of the footwall and hanging-wall sections of the offset moraine using the PolyWorks software package (Fig. DR7). In this section, we discuss the modeling and 
variability of the best-fit planes and compare the angular difference of the piercing line vectors defined by the moraine-crest-reconstruction and vector-fit techniques.

\section{Best-Fit Planes to Moraine Side-Slopes}

At the thirteen locations (see Modeled Tectonic Displacements below), four planes of varying size were mathematically defined from planar sections of the bare-earth point cloud data by using a linear regression. To maximize the far-field reach of the bestfit planes, we identified planar sections of the side slopes in a 3D environment, and excluded the non-planar elements such as moraine crests, transitions to swales or valley bottoms (colluvial wedges), footwall antiforms, and hanging-wall synforms.

Variability of these planar sections of the bare-earth point cloud arises from the natural surface roughness of the moraine side slopes (protruding boulders), and potentially from incorrectly classified LiDAR points (i.e., vegetation returns that have been identified as ground points). The root-mean-square error of the modeled plane that was fit to the bare-earth point cloud provides a quantitative estimate of the roughness and thickness of the planar sections of the bare-earth point cloud; however, we cannot distinguish the relative contributions of the sources of the variability. The average RMS error of the modeled planes described above was $0.39 \mathrm{~m}$ over an average area of 4190 square meters. In other terms, on average $95 \%$ of the point cloud was within $\pm 0.4 \mathrm{~m}$ of the best-fit plane over an average area of 4190 square meters. 


\section{Comparison of Piercing-Line Vectors Defined by Moraine-Crest-Reconstruction and Vector-Fit Techniques}

When we conceived the moraine-crest-reconstruction technique for defining piercing-line vectors, we recognized the need for a comparison with a more conventional approach such as projecting the longitudinal profiles of the footwall and hanging-wall moraine crests into the fault. To avoid under-utilization of the three dimensionality of the LiDAR data (reducing it to a two dimensional profile), we conceived of the vector-fit technique. This more conventional approach uses LiDAR ground points along the moraine crest to define a vector (piercing line) with a linear regression. At every site where we modeled piercing-line vectors with the moraine-crest-reconstruction technique, we have also used the vector-fit technique.

To assess the applicability of the moraine-crest-reconstruction technique to determining the tectonic displacement of lateral moraines, we compared the difference in trend (azimuth in the horizontal plane) and plunge (angle below the horizontal in a vertical plane) between the footwall and hanging-wall piercing-line vectors defined by the two techniques. At the thirteen locations where we have used both techniques, the average difference in trend is $1.1^{\circ}$ and the average difference in plunge is $0.5^{\circ}$. The nominal angular differences between the footwall and hanging-wall piercing line vectors shows a strong coherence between the two techniques and demonstrates the applicability of the moraine-crest-reconstruction technique. These small angular differences translate into the range of displacement solutions presented for each modeled displacement in the 'Modeled Tectonic Displacements' section and Table DR3. There, we report the average vertical separation and the range of values derived from the two techniques for each 
modeled displacement $(n=6$; piercing lines from the two techniques intersecting with the $50^{\circ}, 60^{\circ}$, and $70^{\circ}$ dipping fault planes). The range of values of displacement, at locations where we have used both model techniques, provides a quantitative comparison of the results derived from the two techniques. The range of displacement solutions has been propagated into the error budget of the calculated slip rates (see Root-Mean-Square Error Estimates below).

It is worth noting that direct field measurements of tectonic displacement across faults likely have greater errors than our new technique. The greater errors are due to the subjectivity of identifying the far-field trend of the linear landform in densely vegetated terrain, which compounds the problem of defining the positions of piercing points in the plane of the fault. Our new moraine-crest-reconstruction technique, which utilizes mathematical regressions of thousands to tens of thousands of data points to define planes and vectors from large areas, is much less subjective and far more robust statistically than direct field measurement.

\section{ROOT-MEAN-SQUARE ERROR ESTIMATES}

RMS error calculation for individual offsets and the aggregate sums are described below.

Error assessment of the vertical separation rate and extension rate for a particular offset has been calculated with the following equation:

$$
\mathrm{RMS} \text { error }=(\mathrm{VSR}) \times \sqrt{ }\left[\left(\mathrm{VS}_{\text {error }} / \mathrm{VS}\right)^{2}+\left(\text { Age }_{\text {error }} / \mathrm{Age}\right)^{2}\right]
$$


where (VSR) is the vertical separation rate calculated from the average vertical separation (VS) determined from the displacement models and the average age (Age) of the faulted deposit, $\mathrm{VS}_{\text {error }}$ is the \pm uncertainty of the modeled displacement in meters and Age error is the \pm uncertainty for the average age of the faulted deposit in $10^{3}$ years. For example, using the left-lateral Tioga moraine at Emerald Bay (Table DR3), the VSR is $0.65 \mathrm{~mm} / \mathrm{yr}$, the VS error is $0.5 \mathrm{~m}$, the VS is $15.2 \mathrm{~m}$, the Age error is $3 \times 10^{3}$ years, and the average age is $23.5 \times 10^{3}$ years.

$$
\begin{aligned}
\text { RMS error } & =0.65 \times \sqrt{ }\left[(0.5 / 15.2)^{2}+(3 / 23.5)^{2}\right] \\
& =0.09 \mathrm{~mm} / \mathrm{yr}
\end{aligned}
$$

Error assessment for an aggregate separation rate across the width of a fault zone has been calculated with the following equation:

RMS error $=\left(\mathrm{VSR}_{\text {sum }}\right) \times \sqrt{ }\left[\left(\mathrm{VS}_{\text {error }} / \mathrm{VSR}_{\mathrm{FA}}\right)^{2}+\left(\mathrm{VS}_{\text {error }} / \mathrm{VS}_{\mathrm{FB}}\right)^{2}+\left(\mathrm{VS}_{\text {error }} / \mathrm{VS}_{\mathrm{FC}}\right)^{2}\right]$ (eq. 3)

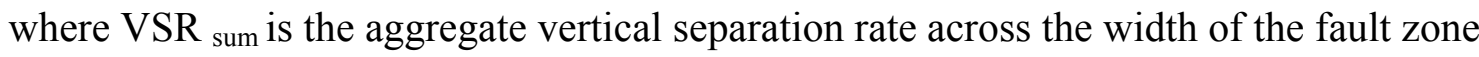
in $\mathrm{mm} / \mathrm{yr}, \mathrm{VS}_{\text {error }}$ is the error in the vertical separation rate at fault A determined from equation 2 above in $\mathrm{mm} / \mathrm{yr}$, and $\mathrm{VSR}_{\mathrm{FA}}$ is the vertical separation rate at fault $\mathrm{A}$ (fault $\mathrm{B}$, etc.) calculated from the average vertical separation from the displacement models and the average age of the faulted deposit in $\mathrm{mm} / \mathrm{yr}$. For example, using the offsets of the General Creek right-lateral moraine at faults A, B, and C (Table DR3),

$$
\begin{aligned}
\text { RMS error } & =\left(\mathrm{VSR}_{\text {sum }}\right) \times \sqrt{ }\left[\left(\mathrm{VS}_{\text {error }} / \mathrm{VSR}_{\mathrm{FA}}\right)^{2}+\left(\mathrm{VS}_{\text {error }} / \mathrm{VS}_{\mathrm{FB}}\right)^{2}+\left(\mathrm{VS}_{\text {error }} / \mathrm{VS}_{\mathrm{FC}}\right)^{2}\right] \\
& =(1.32) \times \sqrt{ }\left[(0.04 / 0.26)^{2}+(0.06 / 0.32)^{2}+(0.10 / 0.74)^{2}\right]
\end{aligned}
$$


$=0.37 \mathrm{~mm} / \mathrm{yr}$

\section{MODELED TECTONIC DISPLACEMENTS}

\section{Range-Front Offset of McKinney Creek - General Creek Medial Tahoe Moraine}

The range-front offset of the McKinney - General medial moraine complex provides a clear example of a range-front offset and hanging-wall graben. The bedrockcored footwall is mantled with Tahoe-age till. This till is truncated and has been displaced across a hanging-wall graben, which is bounded by antithetic scarps (Fig. DR10). The far-field, triangular, cross-sectional shape of the footwall and hanging-wall allows for a robust analysis of post-Tahoe displacement using both the moraine-crestreconstruction and vector-fit techniques. These modeling techniques yielded VS of $44.2 \pm 1.0 \mathrm{~m}$ and extension of $25.4 \pm 0.5 \mathrm{~m}$ that, when combined with the limiting age of $70 \pm 6 \mathrm{ka}$, gave a vertical separation rate of $0.6 \pm 0.06 \mathrm{~mm} / \mathrm{yr}$ and an extension rate $0.4 \pm 0.03$ $\mathrm{mm} / \mathrm{yr}$.

\section{McKinney Creek - General Creek Medial Tahoe Moraine at Fault B}

Near the northern end of the Rubicon Peak segment where less displacement has occurred than to the south, an extensional fault-propagation fold occurs at fault B in the Tahoe medial moraine between McKinney and General creeks (Fig. DR13; see Fig. DR5 for geologic map). At this locality, the linear and evenly graded Tahoe moraine crest has been displaced over a relatively short distance. Instead of a scarp, displacement along the fault has formed a footwall synform and hanging-wall antiform. Geomorphic evidence 
indicates that this fold is a tectonic, rather than a depositional feature. If the feature had formed instead by ice flowing over a pre-existing scarp, the footwall moraine crest should bifurcate at the fault trace; forming two crests on the hanging wall, as observed elsewhere in the study area (see fault-propagation folds in tectonic geomorphology section). Additionally, the 3D moraine-crest-reconstruction model at this site shows that the trends of the footwall and hanging-wall piercing line vectors only differ by $1.2^{\circ}$ and the angle between the vectors in the vertical plane only varies by $1.8^{\circ}$. The near parallelism of these linear and evenly graded moraine crests on both sides of the monoclinal step in the moraine crest further supports our tectonic interpretation (i.e., a displaced linear form). The far-field moraine-crest-reconstruction and vector-fit models produced VS of $19.8 \pm 0.7 \mathrm{~m}$ and extension of $11.4 \pm 0.4 \mathrm{~m}$ in the Tahoe moraine at fault $\mathrm{B}$, and a vertical separation rate of $0.3 \pm 0.03 \mathrm{~mm} / \mathrm{yr}$ and an extension rate $0.2 \pm 0.02 \mathrm{~mm} / \mathrm{yr}$.

\section{Range-Front Offset of General Creek Right-Lateral Tioga Moraine}

At the range front on the south side of General Creek a prominent, truncated bedrock spur has a 100-m-high triangular facet and an adjacent hanging-wall graben (note antithetic scarp in Meeks Creek left-lateral Tioga moraine, Fig. DR11A). On the north side of the triangular facet, range-front fault A has displaced the General Creek right-lateral Tioga maximum moraine just northeast of the point where it abuts bedrock (Fig. DR11B; see Fig. DR5 for geologic map and location). The offset produced a distinct step in the otherwise linear crest of the Tioga maximum moraine. The modeled offset using both the moraine-crest-reconstruction and vector-fit techniques, gave VS of $6.0 \pm 0.4 \mathrm{~m}$ and extension of $3.5 \pm 0.2 \mathrm{~m}$. Using the limiting age of $23.5 \pm 3 \mathrm{ka}$ for the Tioga 
maximum moraine, the vertical separation rate is $0.3 \pm 0.04 \mathrm{~mm} / \mathrm{yr}$ and the extension rate is $0.2 \pm 0.02 \mathrm{~mm} / \mathrm{yr}$.

\section{General Creek Right-Lateral Tioga Moraine at Fault B}

Approximately $1 \mathrm{~km}$ down valley from the range-front offset, a comparable amount of offset occurs in the Tioga maximum moraine across fault B. This offset formed a fault-propagation fold expressed as a monoclinal warp in the Tioga moraine crest with imbricate side-slope scarps (Fig. DR14). This feature is aligned with a prominent scarp in the adjacent Tahoe medial moraine and Meeks Creek left-lateral Tioga moraine to the southeast (Fig. 7A). The moraine-crest-reconstruction and vector-fit models were used here to obtain a VS of $7.5 \pm 0.9 \mathrm{~m}$ and an extension of $4.3 \pm 0.5 \mathrm{~m}$, which yielded a vertical separation rate of $0.3 \pm 0.06 \mathrm{~mm} / \mathrm{yr}$ and an extension rate of $0.2 \pm 0.03$ $\mathrm{mm} / \mathrm{yr}$.

\section{General Creek Right-Lateral Tioga Moraine at Fault C}

At fault C, the General Creek right-lateral Tioga moraine is truncated and has been displaced by fault $\mathrm{C}$ across a large, compound scarp. This dramatic offset and scarp (Fig. DR6) were discussed above in the example of the moraine-crest-reconstruction technique (Fig. DR7). At this site, the displacement of the linear and evenly graded Tioga moraine on both sides of the fault has been modeled using the dual methodology to obtain a VS of $17.3 \pm 0.5 \mathrm{~m}$ and an extension of $10.0 \pm 0.2 \mathrm{~m}$. Using the limiting age of $23.5 \pm 3 \mathrm{ka}$, the vertical separation rate is $0.7 \pm 0.10 \mathrm{~mm} / \mathrm{yr}$ and the extension rate is $0.4 \pm 0.05 \mathrm{~mm} / \mathrm{yr}$. 


\section{Meeks Creek Left-Lateral Tioga Moraine at Faults B and C}

The Meeks Creek left-lateral Tioga moraine has been displaced at three places by faults B and $\mathrm{C}$, which resulted in a series of fault-bounded steps in the Tioga moraine crest (Fig. 7A and Fig. DR8). These offsets provide a good example of the progression in deformation of a moraine crest where there is a thick section of unconsolidated glacial till above a blind bedrock fault or faults at depth. At this site the glacial till is at least $250 \mathrm{~m}$ thick. Initially an upward propagating fault will cause a drape fold or monoclinal warp in the moraine crest (eastern splay of fault C). With continued displacement and upward propagation of the fault tip a step-like fold with footwall antiform and hanging-wall synform develops (western splay of fault C). Ultimately the fault tip will reach the surface and displace the footwall antiform and hanging-wall synform in the moraine crest which are then separated by scarp (fault B).

Offset of the Tioga moraine crest at fault B forms a dramatic step with a large intervening scarp that separates the linear moraine crests on both sides of fault B. Because the Tioga moraine in the footwall of fault B lacks planar side slopes, we have used the vector-fit technique to define the piercing-line vector here. In the hanging wall of fault B, however, the morphology of the moraine crest allows the use of both the moraine-crest-reconstruction and the vector-fit techniques. These models yielded VS of $20.3 \pm 0.8 \mathrm{~m}$ and an extension of $11.8 \pm 0.4 \mathrm{~m}$ across fault $\mathrm{B}$, which in turn yielded a vertical separation rate of $0.9 \pm 0.11 \mathrm{~mm} / \mathrm{yr}$ and an extension rate of $0.5 \pm 0.07 \mathrm{~mm} / \mathrm{yr}$.

Where fault $\mathrm{C}$ offsets the Meeks Creek left-lateral Tioga moraine, it splays and forms an imbricate zone of faults (Fig. 7A and Fig. DR8). The western splay produced a step-like fault-propagation fold in the moraine crest, with a footwall antiform and 
hanging-wall synform, while the eastern splay of fault $\mathrm{C}$ has formed a monoclinal warp in the moraine crest. Because the short segment of moraine crest between the two splays of fault C lacks planar side-slopes, we have used only the vector-fit technique to define the piercing-line vector here. The moraine crests in both the footwall of the western splay and the hanging wall of the eastern splay are well preserved, however, allowing the use of both the moraine-crest-reconstruction and the vector-fit techniques. These models yielded combined VS of $17.6 \pm 2.0 \mathrm{~m}$ and extension of $10.2 \pm 1.0$ across the two strands of fault C (Fig. DR8B), which compares well with the offset right-lateral Tioga moraine at General Creek (Table DR3). Using the limiting age of $23.5 \pm 3 \mathrm{ka}$, the vertical separation rate is $0.4 \pm 0.08 \mathrm{~mm} / \mathrm{yr}$ and the extension rate is $0.2 \pm 0.04 \mathrm{~mm} / \mathrm{yr}$ for the western splay of fault $\mathrm{C}$, and the vertical separation rate is $0.3 \pm 0.05 \mathrm{~mm} / \mathrm{yr}$ and the extension rate is $0.2 \pm 0.03 \mathrm{~mm} / \mathrm{yr}$ for the eastern splay of fault C (Table DR3).

\section{Meeks Creek Right-Lateral Moraines at the Range Front}

The Meeks Creek right-lateral moraines, as well as the medial moraine complex between Meeks and General Creeks, display all elements of the tectonic geomorphology discussed above (see Tectonic Geomorphology section). Along the range-front fault A, truncated bedrock spurs form triangular facets. At the bases of the facets, where the lateral moraines abut the crystalline bedrock, relatively narrow hanging-wall graben occur (Fig. 6). Northeast of the main range-front fault (fault A), the imbricate Rubicon Peak fault zone forms another set of large triangular facets in the Tahoe moraines on both sides of Meeks Creek. Broad grabens occur in the hanging walls of these facets (Fig. 6). In both moraine complexes, in the hanging walls of the faults, the Tahoe moraine is 
topographically reversed relative to the flanking Tioga moraines (range-front tectonic reversals). In the outer slope (south side) of the Meeks right-lateral Tahoe moraine, welldeveloped, fault-controlled side-slope troughs are aligned with scarps on the Tioga moraine crest. These scarps in turn are aligned with degraded scarps on the north side of the moraine complex (Fig. DR9E). Back-tilted segments of the Tahoe moraines, on both sides of Meeks Creek, occur directly east of the hanging-wall grabens (Fig. 6 and Fig. DR9A). Note that in the Meeks Creek right-lateral Tahoe moraine (right side of Fig. DR9A and 9B), displacement along a shallowly dipping antithetic fault has nearly leveled the westward back-tilted moraine. This has formed a gentle warp in the slope and a change in trend of the broader, back-tilted section of Tahoe moraine crest.

\section{Range-Front Offset of Meeks Creek Right-Lateral Tahoe Moraine}

Displacement of the Meeks Creek right-lateral Tahoe moraine at the range front has formed a 70-m-high triangular facet, a 380-m-wide hanging-wall graben, and a 460m-long, back-tilted segment of moraine crest (Fig. DR9A). The apparent displacement of the Tahoe moraine crest at the range front is greater than the actual net tectonic vertical separation (NTVS) because antithetic displacement has occurred on the northeast side of the hanging-wall graben (Fig. DR9A and 9B). At this site, we have estimated the NTVS across the graben and several fault strands from the difference in elevation between the highest point of the Tahoe moraine on the footwall $(2197 \mathrm{~m})$ and the elevation of the Tahoe moraine crest in the hanging wall northeast of the graben. Using the LiDAR imagery, we defined two points along the back-tilted hanging-wall moraine [hanging wall maximum throw point $(2140 \mathrm{~m})$ and hanging wall minimum throw point $(2152 \mathrm{~m})$, 
respectively; Fig. DR9B]. The maximum-throw point of the hanging wall conservatively represents the top of the antithetic structure bounding the hanging-wall graben and the minimum-throw point of the hanging wall is a minimum because it has been rotated upwards (back-tilted) above its primary depositional elevation. The difference in elevation between the high point of the footwall and the two hanging-wall points produces a NTVS estimate of $51 \pm 6 \mathrm{~m}$ and an extension estimate of $29 \pm 3.5 \mathrm{~m}$, assuming a 60 degree dipping fault plane. These estimates combined with the Tahoe limiting age of $70 \pm 6 \mathrm{ka}$ yielded a vertical separation rate of $0.7 \pm 0.11 \mathrm{~mm} / \mathrm{yr}$ and an extension rate $0.4 \pm 0.09 \mathrm{~mm} / \mathrm{yr}$

\section{Range-Front Offset of Meeks Creek Right-Lateral Tioga Moraine}

The range-front fault that traverses the base of the $\sim 70$-m-high triangular facet discussed above (fault B in Fig. DR5) also displaces the right-lateral Tioga maximum moraine (Fig. DR9C and 9D). The moraine-crest morphology on both sides of the distinct scarp allows for both the moraine-crest-reconstruction and vector-fit modeling of displacement, which yielded a VS of $12.6 \pm 1.2 \mathrm{~m}$ and an extension of $7.3 \pm 0.6 \mathrm{~m}$. Using the limiting age of $23.5 \pm 3 \mathrm{ka}$, the minimum vertical separation rate is $0.5 \pm 0.09 \mathrm{~mm} / \mathrm{yr}$ and the extension rate is $0.3 \pm 0.05 \mathrm{~mm} / \mathrm{yr}$. Along the range-front fault $\mathrm{B}$ at the Meeks

Creek right-lateral moraines, the post-Tahoe $(0.7 \pm 0.11 \mathrm{~mm} / \mathrm{yr})$ and post-Tioga $(0.5 \pm 0.09$ $\mathrm{mm} / \mathrm{yr}$ ) vertical separation rates are in general agreement. 


\section{Meeks Creek Right-Lateral Tioga Moraine at Fault D}

Where fault D cuts the Meeks Creek right-lateral moraine complex, a deep sideslope trough occurs in pre-Tahoe deposits on the south side of the complex, a side-slope scarp is developed in the Tahoe-age till, and a scarp in the Tioga maximum moraine crest is aligned with a small but abrupt scarp in the Tioga recessional moraine on the north side of the complex (Fig. DR9B, 9E, and 9F). The two modeling techniques applied to the Tioga crest yielded VS of $2.9 \pm 0.2 \mathrm{~m}$ and an extension of $1.7 \pm 0.1 \mathrm{~m}$. Using the limiting age of $23.5 \pm 3 \mathrm{ka}$, the nominal vertical separation rate is $0.1 \pm 0.02 \mathrm{~mm} / \mathrm{yr}$.

\section{Meeks Creek Right-Lateral Tahoe Moraine at Fault E}

Where fault E cuts the Meek Creek right-lateral moraines it separates the westward- (back-tilted) and eastward-sloping sections of the Tahoe moraine crest (Fig. DR15; see Fig. DR5 for geologic map and location). We have interpreted the morphology of the Tahoe moraine at fault $\mathrm{E}$ to have been influenced by both depositional and postdepositional tectonic processes. The Tahoe moraine at this location is a prime example of a moraine that was deposited over a pre-existing (i.e., pre-Tahoe) scarp. As the Tahoe glacier flowed down the scarp, the velocity increased and the cross-sectional area of the glacier decreased, causing the moraine crest to curve into the valley, and also forming a steep easterly slope in the moraine crest. While this depositional process explains the change in trend and gradient of the moraine crest east of fault $\mathrm{E}$, it does not account for the abrupt offset of the Tahoe moraine crest, which we have attributed to postdepositional fault displacement. At this location, we have used the dual methodology 
which yielded VS of $12.5 \pm 3.0 \mathrm{~m}$ and an extension of $7.2 \pm 1.5 \mathrm{~m}$. When combined with the limiting age of $70 \pm 6 \mathrm{ka}$, the vertical separation rate is $0.2 \pm 0.05 \mathrm{~mm} / \mathrm{yr}$ and the extension rate is $0.1 \pm 0.02 \mathrm{~mm} / \mathrm{yr}$.

\section{Meeks Creek Right-Lateral Tioga Moraine at Fault E}

Along strike, $200 \mathrm{~m}$ north of the offset Tahoe moraine crest described above, fault E displaces the crest of the Tioga maximum moraine. A prominent side-slope scarp and trough are aligned with the scarp in the Tioga moraine crest (Fig. 7B and Fig. DR15). At this location, we have utilized very high-resolution $(\sim 2 \mathrm{~cm}$ laser spot spacing) terrestrial or tripod LiDAR (T-LiDAR) to resolve the tectonic displacement. Using T-LiDAR, we imaged the Tioga maximum moraine for $\sim 100$ meters on both sides of fault $\mathrm{E}$. The TLiDAR bare-earth model has an average data density of $>600$ points per $\mathrm{m}^{2}$, over two orders of magnitude greater than the data density of airborne LiDAR. To model the farfield orientation of fault E, we aligned (combined) the terrestrial and airborne data sets to produce a composite, georeferenced point cloud. Using the dual methodology, we resolved VS of $4.2 \pm 0.6 \mathrm{~m}$ and an extension of $2.4 \pm 0.3 \mathrm{~m}$. Using the limiting age of $23.5 \pm 3 \mathrm{ka}$, yielded a vertical separation rate of $0.2 \pm 0.03 \mathrm{~mm} / \mathrm{yr}$ and an extension rate of $0.1 \pm 0.02 \mathrm{~mm} / \mathrm{yr}$. Along fault $\mathrm{E}$ the post-Tahoe vertical separation rate $(0.2 \pm 0.05 \mathrm{~mm} / \mathrm{yr})$ and post-Tioga vertical separation rate $(0.2 \pm 0.03 \mathrm{~mm} / \mathrm{yr})$ are in good agreement.

\section{Left-Lateral Tioga and Tahoe Moraines of Emerald Bay at the Range-Front Fault}

Near the southern end of the Rubicon Peak fault, the range-front fault strands displaced the Tioga and Tahoe left-lateral moraines (McCaughey, 2003) on the north side of Emerald Bay (Fig. 5 and Fig. DR16). There, multiple fault strands form an imbricate 
$\sim 175$-m-wide fault zone. Using both the moraine-crest-reconstruction and vector-fit techniques, we obtained VS of $15.2 \pm 0.5 \mathrm{~m}$ and an extension of $8.8 \pm 0.2 \mathrm{~m}$ in the Tioga moraine. This yielded a vertical separation rate of $0.6 \pm 0.09 \mathrm{~mm} / \mathrm{yr}$ and an extension rate of $0.4 \pm 0.05 \mathrm{~mm} / \mathrm{yr}$, since $23.5 \pm 3 \mathrm{ka}$. For the Tahoe moraine across this same zone, we obtained VS of $30.1 \pm 6.9 \mathrm{~m}$ and an extension of $17.4 \pm 3.9 \mathrm{~m}$. These offsets of the Tahoe moraine yield a vertical separation rate of $0.4 \pm 0.11 \mathrm{~mm} / \mathrm{yr}$ and an extension rate of $0.2 \pm 0.06 \mathrm{~mm} / \mathrm{yr}$, since $70 \pm 6 \mathrm{ka}$.

About $60 \mathrm{~m}$ along strike to the southeast of the offset Tioga maximum moraine, a section of a Tioga recessional moraine spanning the Rubicon Peak fault collapsed into Emerald Bay in a landslide (see Fig. 5 and Fig. DR2 for geologic map). This landslide may have been seismically triggered by the latest Pleistocene/ Holocene (?) offset of the Tioga maximum moraine. As previously noted in the text, still younger scarps cut the landslide deposit (Figs. 4 and 5).

\section{DATA REPOSITORY REFERENCES}

Balco, G., Stone, J.O., Lifton, N.A., and Dunai, T.J., 2008, A complete and easily accessible means of calculating surface exposure ages or erosion rates from ${ }^{10} \mathrm{Be}$ and ${ }^{26} \mathrm{Al}$ measurements: Quaternary Geochronology, v. 3, p. 174-195, doi:10.1016/j.quageo.2007.12.001.

Berger, G.W., 1990, Effectiveness of natural zeroing of the thermoluminescence in sediments: Journal of Geophysical Research, v. 95, p. 12,375-12,397, doi:10.1029/JB095iB08p12375.

Berger, G.W., Post, S., and Wenker, C., 2009, Single and multigrain quartz-luminescence dating of irrigation-channel features in Santa Fe, New Mexico: Geoarchaeology, v. 24, p. 383-401, doi:10.1002/gea.20271.

Blackwelder, E., 1931, Pleistocene glaciation in the Sierra Nevada and Basin Ranges: Geological Society of America Bulletin, v. 42, p. 865-922. 
Carter, W.E., Shrestha, R.L., and Slatton, K.C., 2007, Geodetic laser scanning: Physics Today, v. 60, p. 41-47, doi:10.1063/1.2825070.

Gosse, J.C., and Phillips, F.M., 2001, Terrestrial in situ cosmogenic nuclides: Theory and application: Quaternary Science Reviews, v. 20, p. 1475-1560, doi:10.1016/S02773791(00)00171-2.

Heisinger, B., 2002a, Production of selected cosmogenic radionuclides by muons: 1. Fast muons: Earth and Planetary Science Letters, v. 200, p. 345-355, doi:10.1016/S0012$821 \mathrm{X}(02) 00640-4$.

Heisinger, B., 2002b, Production of selected cosmogenic radionuclides by muons: 2 . Capture of negative muons: Earth and Planetary Science Letters, v. 200, p. 357-369, doi:10.1016/S0012-821X(02)00641-6.

Lal, D., 1991, Cosmic ray labeling of erosion surfaces: In situ nuclide production rates and erosion models: Earth and Planetary Science Letters, v. 104, p. 424-439, doi:10.1016/0012-821X(91)90220-C.

Lal, D., and Arnold, J.R., 1985, Tracing quartz through the environment: Earth and Planetary Science Letters, v. 94, p. 1-5.

Murray, A.S., and Olley, J.M., 2002, Precision and accuracy in the optically stimulated luminescence dating of sedimentary quartz: A status review: Geochronometria, v. 21, p. $1-16$.

Murray, A.S., and Wintle, A.G., 2000, Luminescence dating of quartz using an improved single-aliquot regenerative-dose protocol: Radiation Measurements, v. 32, p. 57-73, doi:10.1016/S1350-4487(99)00253-X.

Murray, A.S., and Wintle, A.G., 2003, The single-aliquot regenerative dose protocol: Potential for improvements in reliability: Radiation Measurements, v. 37, p. 377-381, doi:10.1016/S1350-4487(03)00053-2.

Nishiizumi, K., Imamura, M., Caffee, M.W., Southon, J.R., Finkel, R.C., and McAninch, J., 2007, Absolute calibration of ${ }^{10}$ Be AMS standards: Nuclear Instruments \& Methods in Physics Research, Section B, Beam Interactions with Materials and Atoms, v. 258, no. 2, p. 403-413, doi:10.1016/j.nimb.2007.01.297.

Rood, D.H., Burbank, D.W., and Finkel, R.C., 2011, Chronology of glaciations in the Sierra Nevada, California, from ${ }^{10} \mathrm{Be}$ surface exposure dating: Quaternary Science Reviews, v. 30, p. 646-661, doi:10.1016/j.quascirev.2010.12.001.

Stone, J.O., 2000, Air pressure and cosmogenic isotope production: Journal of Geophysical Research, v. 105, no. B10, p. 23,753-23,759, doi:10.1029/2000JB900181. 
DATA REPOSITORY TABLE 1. TCN EXPOSURE AGES OF MEEKS CREEK SAMPLES ASSUMING $1.0 \mathrm{~m} / \mathrm{Ma}$ EROSION RATE

\begin{tabular}{cccccc}
\hline \hline $\begin{array}{c}\text { Sample } \\
\text { Identifier }\end{array}$ & $\begin{array}{c}{ }^{10} \mathrm{Be} \text { exposure } \\
\text { age }(\mathrm{ka})\end{array}$ & $\begin{array}{c}{ }^{26} \mathrm{Al} \text { exposure } \\
\text { age }(\mathrm{ka})\end{array}$ & $\begin{array}{c}\text { Mean }\left({ }^{10} \mathrm{Be} \text { and }{ }^{26} \mathrm{Al}\right) \\
\text { exposure age }(\mathrm{ka})\end{array}$ & $\begin{array}{c}\text { Mean surface } \\
\text { erosion }(\mathrm{mm})^{\star}\end{array}$ \\
\hline MC1 & $45.9 \pm 4.4$ & $47.7 \pm 4.5$ & $46.8 \pm 3.1$ & 27.5 & $\mathrm{n}=6$ \\
MC2 & $69.8 \pm 6.7$ & $68.6 \pm 6.8$ & $69.2 \pm 4.8$ & 48.6 & $\mathrm{n}=8$ \\
MC3 & $20.7 \pm 1.9$ & $20.9 \pm 2.0$ & $20.8 \pm 1.4$ & 23.1 & $\mathrm{n}=8$ \\
MC4 & $20.1 \pm 1.9$ & $21.4 \pm 2.0$ & $20.7 \pm 1.4$ & 19.0 & $\mathrm{n}=5$ \\
\hline
\end{tabular}

* $\mathrm{n}$ is the number of height measurements made. Exposure age uncertainties are the 1 standard deviation external uncertainties derived from the CRONUS on-line calculator (Balco et al., 2008). They include the analytical uncertainty in the ${ }^{10} \mathrm{Be}$ and ${ }^{26} \mathrm{Al}$ determinations and the uncertainty in the reference nuclide production rate for spallation derived from the scatter in the scaled calibration measurements and the uncertainty in the nuclide production rate by muons. The means of the ${ }^{10} \mathrm{Be}$ and ${ }^{26} \mathrm{Al}$ ages are weighted means. All uncertainties are absolute. 
DATA REPOSITORY TABLE 2. MEEKS CREEK TCN SAMPLE DETAILS

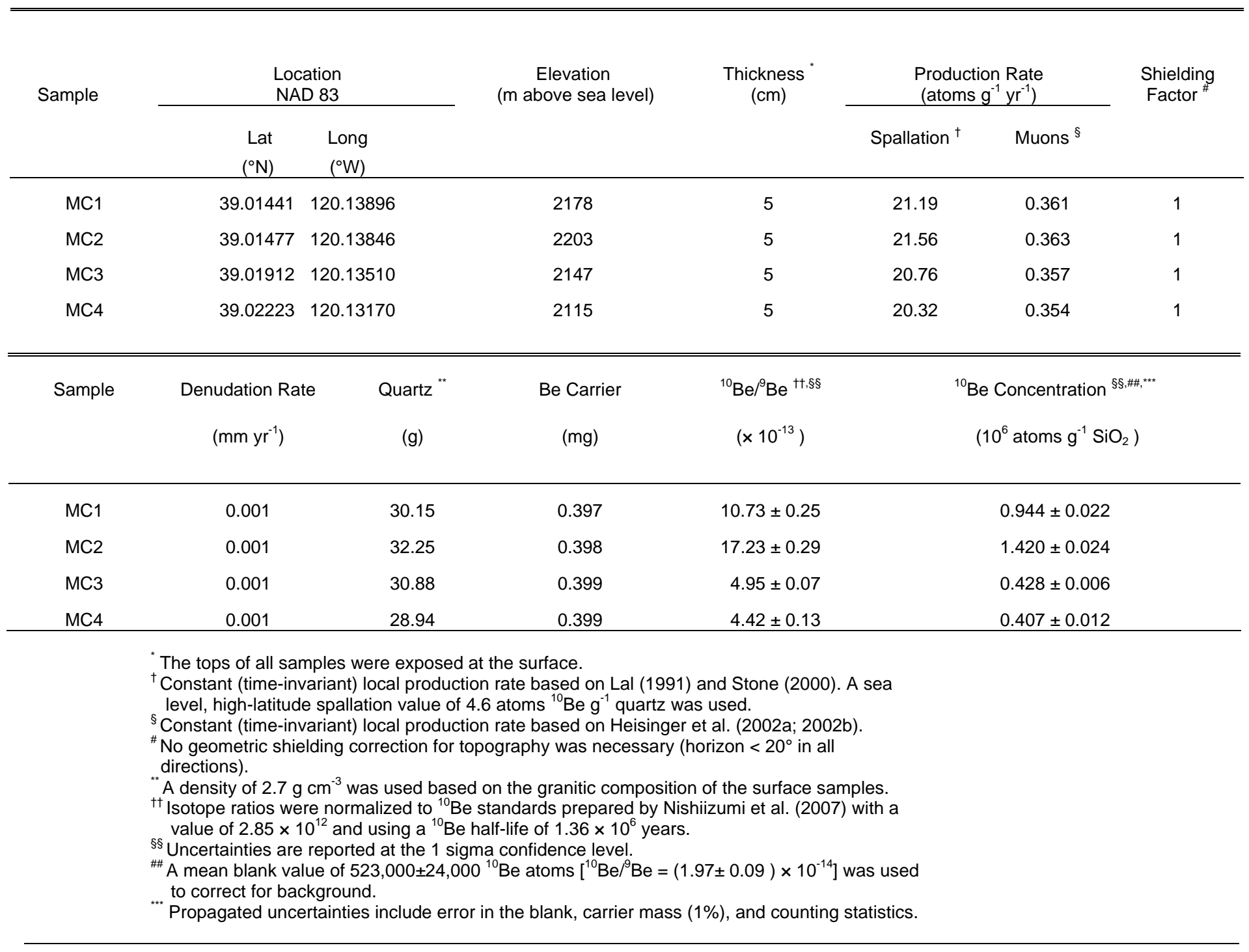


DATA REPOSITORY TABLE 3. MODELED OFFSETS, VERTICAL SEPARATION RATES, AND EXTENSION RATES FOR FAULTS OF THE RUBICON PEAK SEGMENT

\begin{tabular}{|c|c|c|c|c|}
\hline \multicolumn{5}{|c|}{ McKinney Creek - General Creek Medial Tahoe Moraine } \\
\hline Moraine & Fault A & Fault B & & $\begin{array}{c}\text { Total separation } \\
\text { rate }^{*}\end{array}$ \\
\hline \multirow{2}{*}{\multicolumn{5}{|c|}{$V S=44.2 \pm 1.0 \mathrm{~m}$}} \\
\hline & & & & \\
\hline \multirow[t]{3}{*}{$(70 \pm 6 \mathrm{ka})$} & VSR $=0.63 \pm 0.06$ & VSR $=0.28 \pm 0.03$ & & VSR $=0.9 \pm 0.1$ \\
\hline & $E X=25.4 \pm 0.5 \mathrm{~m}$ & $\mathrm{EX}=11.4 \pm 0.4 \mathrm{~m}$ & N.D. ${ }^{\dagger}$ & \\
\hline & $\mathrm{EXR}=0.36 \pm 0.03$ & $\mathrm{EXR}=0.16 \pm 0.02$ & & $\mathrm{EXR}=0.5 \pm 0.1$ \\
\hline \multicolumn{5}{|c|}{ General Creek Right - Lateral Tioga Moraine } \\
\hline Moraine & Fault A & Fault B & Fault C & $\begin{array}{c}\text { Total separation } \\
\text { rate }^{*}\end{array}$ \\
\hline & VS $=6.0 \pm 0.4 \mathrm{~m}$ & VS $=7.5 \pm 0.9 \mathrm{~m}$ & $\mathrm{VS}=17.3 \pm 0.5 \mathrm{~m}$ & \\
\hline \multirow{4}{*}{$\begin{array}{l}\text { Tioga } \\
(23.5 \pm 3 \mathrm{ka})\end{array}$} & & & & \\
\hline & VSR $=0.26 \pm 0.04$ & VSR $=0.32 \pm 0.06$ & VSR $=0.74 \pm 0.10$ & VSR $=1.3 \pm 0.4$ \\
\hline & $E X=3.5 \pm 0.2 \mathrm{~m}$ & $\mathrm{EX}=4.3 \pm 0.5 \mathrm{~m}$ & $\mathrm{EX}=10.0 \pm 0.2 \mathrm{~m}$ & \\
\hline & $\mathrm{EXR}=0.15 \pm 0.02$ & $\mathrm{EXR}=0.18 \pm 0.03$ & $\mathrm{EXR}=0.42 \pm 0.05$ & $\mathrm{EXR}=0.8 \pm 0.2$ \\
\hline \multicolumn{5}{|c|}{ Meeks Creek Left - Lateral Tioga Moraine } \\
\hline Moraine & Fault B & $\begin{array}{c}\text { Fault C western } \\
\text { splay }\end{array}$ & $\begin{array}{c}\text { Fault C eastern } \\
\text { splay } \\
\end{array}$ & $\begin{array}{c}\text { Total separation } \\
\text { rate }^{*}\end{array}$ \\
\hline \multirow{4}{*}{$\begin{array}{l}\text { Tioga } \\
(23.5 \pm 3 \mathrm{ka})\end{array}$} & $V S=20.3 \pm 0.8 \mathrm{~m}$ & $\mathrm{VS}=10.1 \pm 1.4 \mathrm{~m}$ & $\mathrm{VS}=7.5 \pm 0.6 \mathrm{~m}$ & \\
\hline & VSR $=0.86 \pm 0.11$ & $\mathrm{VSR}=0.43 \pm 0.08$ & VSR $=0.32 \pm 0.05$ & VSR $=1.6 \pm 0.4$ \\
\hline & $\mathrm{EX}=11.8 \pm 0.4 \mathrm{~m}$ & $\mathrm{EX}=5.8 \pm 0.7 \mathrm{~m}$ & $E X=4.4 \pm 0.3 \mathrm{~m}$ & \\
\hline & $\mathrm{EXR}=0.50 \pm 0.07$ & $\mathrm{EXR}=0.25 \pm 0.04$ & $\mathrm{EXR}=0.18 \pm 0.03$ & $\mathrm{EXR}=0.9 \pm 0.2$ \\
\hline \multicolumn{5}{|c|}{ Meeks Creek Right - Lateral Moraine Complex } \\
\hline Moraine & Fault B & Fault D & Fault E & $\begin{array}{c}\text { Total separation } \\
\text { rate }^{*}\end{array}$ \\
\hline \multirow{4}{*}{$\begin{array}{l}\text { Tioga } \\
(23.5 \pm 3 \mathrm{ka})\end{array}$} & $\mathrm{VS}=12.6 \pm 1.2 \mathrm{~m}$ & $\mathrm{VS}=2.9 \pm 0.2 \mathrm{~m}$ & $\mathrm{VS}=4.2 \pm 0.6 \mathrm{~m}$ & \\
\hline & VSR $=0.54 \pm 0.09$ & VSR $=0.12 \pm 0.02$ & VSR $=0.18 \pm 0.03$ & VSR $=0.8 \pm 0.2$ \\
\hline & $\mathrm{EX}=7.3 \pm 0.6 \mathrm{~m}$ & $E X=1.7 \pm 0.1 \mathrm{~m}$ & $E X=2.4 \pm 0.3 \mathrm{~m}$ & \\
\hline & $\mathrm{EXR}=0.31 \pm 0.05$ & $\mathrm{EXR}=0.08 \pm 0.01$ & $\mathrm{EXR}=0.10 \pm 0.02$ & $\mathrm{EXR}=0.5 \pm 0.1$ \\
\hline
\end{tabular}


Meeks Creek Right - Lateral Moraine Complex continued

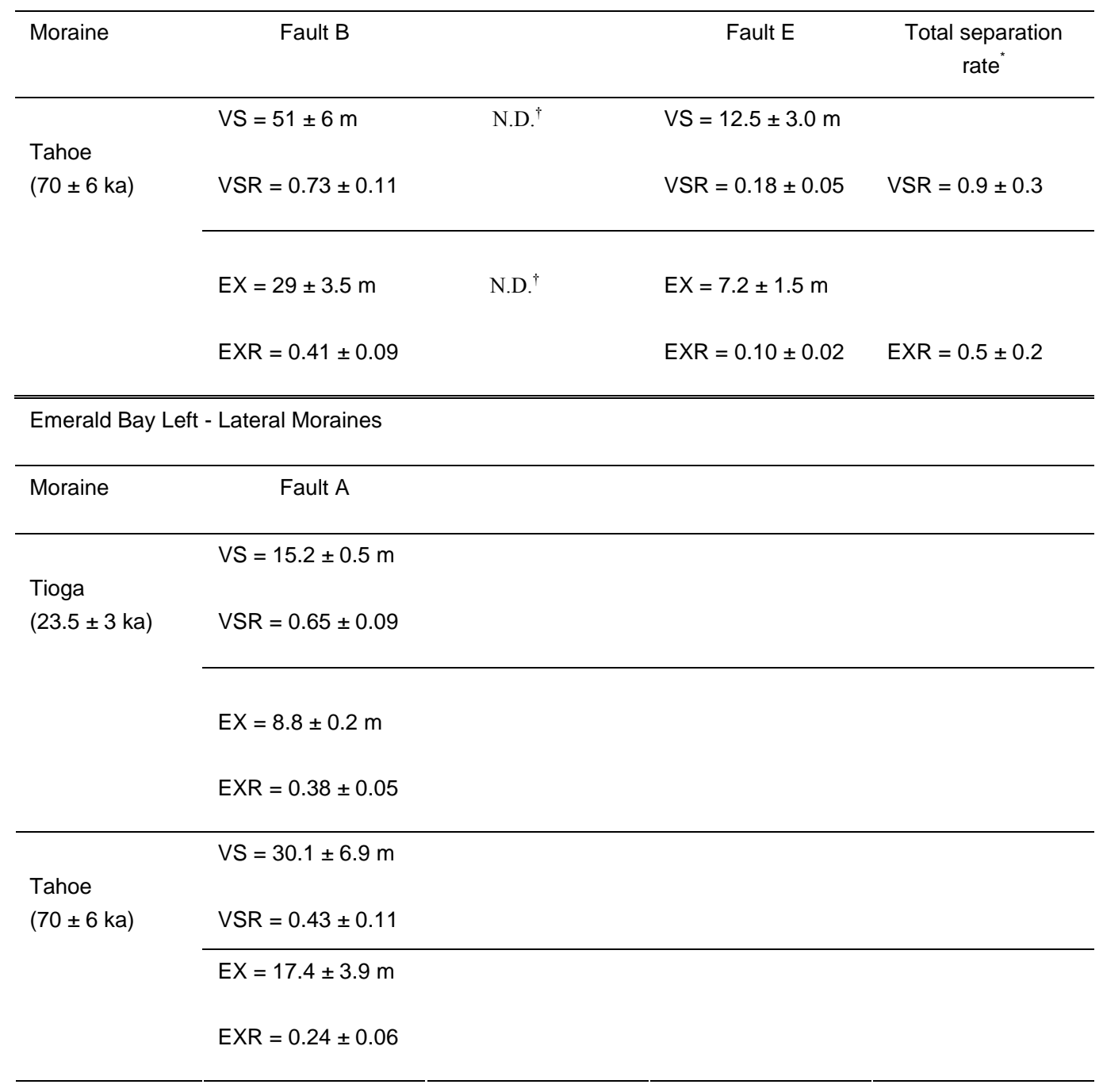

Faults A, B, and C are faults within the Rubicon Peak segment of the TSFFZ. VS, modeled vertical separation and observed spread in displacement models in meters; VSR, vertical separation rate in $\mathrm{mm} / \mathrm{yr}$ and RMS error derived from observed spread in displacement models and age uncertainties; EX, extension, in meters, assuming $60^{\circ}$ dip for fault plane; EXR, extension rate in mm/yr and error derived from observed spread in displacement models and age uncertainties; and corresponding total (aggregate) separation rate across the width of the fault zone based on available strain markers. RMS error estimates represent $a \pm 1$ standard deviation error. See data repository for discussion of RMS error estimates.

* Total separation rate is aggregate rate across measured strands \pm RMS error.

${ }^{\dagger}$ N.D. $=$ No data. 
DATA REPOSITORY TABLE 4. POTENTIAL EARTHQUAKE MAGNITUDES FOR A COSEISMIC RUPTURE OF THE ECHO PEAK AND MT. TALLAC SEGMENTS

\begin{tabular}{ccccc}
\hline \hline $\begin{array}{c}\text { Surface } \\
\text { Rupture } \\
\text { Length } \\
(\mathrm{km})\end{array}$ & $\begin{array}{c}\text { Base of } \\
\text { Seismo- } \\
\text { genic } \\
\text { Zone }(\mathrm{km})\end{array}$ & $\begin{array}{c}\text { Down-Dip } \\
\text { Rupture } \\
\text { Length } \\
(\mathrm{km})\end{array}$ & $\begin{array}{c}\text { Subsurface } \\
\text { Rupture } \\
\text { Area }(\mathrm{RA}) \\
\left(\mathrm{km}^{2}\right)\end{array}$ & $\begin{array}{c}\text { Moment } \\
\text { Magnitude } \\
\left(\mathrm{M}_{\mathrm{w}}\right) \\
\pm 0.25\end{array}$ \\
\hline 20.0 & 10 & 11.5 & 231 & 6.3 \\
20.0 & 14 & 16.2 & 323 & 6.5 \\
20.0 & 18 & 20.8 & 416 & 6.6 \\
\hline 27.0 & 10 & 11.5 & 312 & 6.5 \\
27.0 & 14 & 16.2 & 436 & 6.6 \\
27.0 & 18 & 20.8 & 561 & 6.7 \\
\hline
\end{tabular}

Assuming both the Echo Peak and Mt. Tallac segments rupture coseismically, a fault dip of 60 degrees (for down-dip rupture length and subsurface rupture area), and depths to the base of the seismogenic zone of 10,14 , and $18 \mathrm{~km}$, the equation below was used to estimate earthquake moment magnitudes $\left(\mathrm{M}_{\mathrm{w}}\right)$. The combined range-front sections of the Echo Peak and Mt. Tallac faults is $27.0 \mathrm{~km}$. Also included is the Mt. Tallac segment alone, with a mapped length of $20.0 \mathrm{~km} . \mathrm{M}_{\mathrm{w}}=3.93+(1.02(\log \mathrm{RA}))$; calculates $\mathrm{M}_{\mathrm{w}}$ for normal faults based on subsurface rupture area (RA) in $\mathrm{km}^{2}$ with an error estimate of \pm 0.25 (Wells and Coppersmith, 1994). 
DATA REPOSITORY TABLE 5. POTENTIAL EARTHQUAKE MAGNITUDES FOR RUPTURE SCENARIOS ALONG THE RUBICON PEAK SEGMENT

\begin{tabular}{ccccc}
\hline \hline $\begin{array}{c}\text { Surface } \\
\text { Rupture } \\
\begin{array}{c}\text { Length } \\
(\mathrm{km})\end{array}\end{array}$ & $\begin{array}{c}\text { Base of } \\
\text { Seismo- } \\
\text { genic } \\
\text { Zone }(\mathrm{km})\end{array}$ & $\begin{array}{c}\text { Down-Dip } \\
\text { Rupture } \\
\text { Length } \\
(\mathrm{km})\end{array}$ & $\begin{array}{c}\text { Subsurface } \\
\text { Rupture } \\
\text { Area }(\mathrm{RA}) \\
\left(\mathrm{km}^{2}\right)\end{array}$ & $\begin{array}{c}\text { Moment } \\
\text { Magnitude } \\
\left(\mathrm{M}_{\mathrm{w}}\right) \\
\pm 0.25\end{array}$ \\
\hline 18.0 & 10 & 11.5 & 208 & 6.3 \\
18.0 & 14 & 16.2 & 291 & 6.4 \\
18.0 & 18 & 20.8 & 374 & 6.6 \\
\hline 36.0 & 10 & 11.5 & 416 & 6.6 \\
36.0 & 14 & 16.2 & 582 & 6.8 \\
36.0 & 18 & 20.8 & 784 & 6.9 \\
\hline
\end{tabular}

Assuming a fault dip of 60 degrees (for down-dip rupture length and subsurface rupture area), and depths to the base of the seismogenic zone of 10,14, and $18 \mathrm{~km}$, the following equation was used to estimate earthquake moment magnitudes $\left(M_{w}\right)$ for two rupture scenarios. The first scenario considers only that part of the range-front fault with evidence of late Quaternary displacement (a length of $18 \mathrm{~km}$ ). The second scenario assumes that the entire mapped length of the Rubicon Peak fault ruptures (a length of $36 \mathrm{~km}$ ).

$\mathrm{M}_{\mathrm{w}}=3.93+(1.02(\log \mathrm{RA}))$; calculates $\mathrm{M}_{\mathrm{w}}$ for normal faults based on subsurface rupture area (RA) in $\mathrm{km}^{2}$ with an error estimate of \pm 0.25 (Wells and Coppersmith, 1994). 


\section{DATA REPOSITORY TABLE 6. POTENTIAL EARTHQUAKE MAGNITUDES FOR A COSEISMIC RUPTURE OF THE MT. TALLAC AND RUBICON PEAK SEGMENTS}

\begin{tabular}{ccccc}
\hline \hline $\begin{array}{c}\text { Surface } \\
\text { Rupture } \\
\begin{array}{c}\text { Length } \\
(\mathrm{km})\end{array}\end{array}$ & $\begin{array}{c}\text { Base of } \\
\text { Seismo- } \\
\text { genic } \\
\text { Zone }(\mathrm{km})\end{array}$ & $\begin{array}{c}\text { Down-Dip } \\
\text { Rupture } \\
\text { Length } \\
(\mathrm{km})\end{array}$ & $\begin{array}{c}\text { Subsurface } \\
\text { Rupture } \\
\text { Area }(\mathrm{RA}) \\
\left(\mathrm{km}^{2}\right)\end{array}$ & $\begin{array}{c}\text { Moment } \\
\text { Magnitude } \\
\left(\mathrm{M}_{\mathrm{w}}\right) \\
\pm 0.25\end{array}$ \\
\hline 29.4 & 10 & 11.5 & 339 & 6.5 \\
29.4 & 14 & 16.2 & 475 & 6.7 \\
29.4 & 18 & 20.8 & 611 & 6.8 \\
\hline 33.6 & 10 & 11.5 & 388 & 6.6 \\
33.6 & 14 & 16.2 & 543 & 6.7 \\
33.6 & 18 & 20.8 & 698 & 6.8 \\
\hline 37.8 & 10 & 11.5 & 436 & 6.6 \\
37.8 & 14 & 16.2 & 611 & 6.8 \\
37.8 & 18 & 20.8 & 786 & 6.9 \\
\hline 42.0 & 10 & 11.5 & 485 & 6.7 \\
42.0 & 14 & 16.2 & 679 & 6.8 \\
42.0 & 18 & 20.8 & 873 & 6.9 \\
& & & & \\
\hline
\end{tabular}

Assuming that both the Mt. Tallac fault and Rubicon Peak faults rupture coseismically, a fault dip of 60 degrees (for down-dip rupture length and subsurface rupture area), and depths to the base of the seismogenic zone of 10,14 , and $18 \mathrm{~km}$, the following equation was used to estimate earthquake moment magnitudes $\left(\mathrm{M}_{\mathrm{w}}\right)$. The total mapped length of the Mt. Tallac and Rubicon Peak faults is $42.0 \mathrm{~km}$ and we calculate $M_{w}$ for surface-rupture lengths of 0.7 (29.4 km), 0.8 $(33.6 \mathrm{~km}), 0.9(37.8 \mathrm{~km})$, and $1.0(42.0)$ of the total mapped length. $\mathrm{M}_{\mathrm{w}}=3.93+(1.02(\log \mathrm{RA}))$; calculates $\mathrm{M}_{\mathrm{w}}$ for normal faults based on subsurface rupture area (RA) in $\mathrm{km}^{2}$ with an error estimate of \pm 0.25 (Wells and Coppersmith, 1994). 


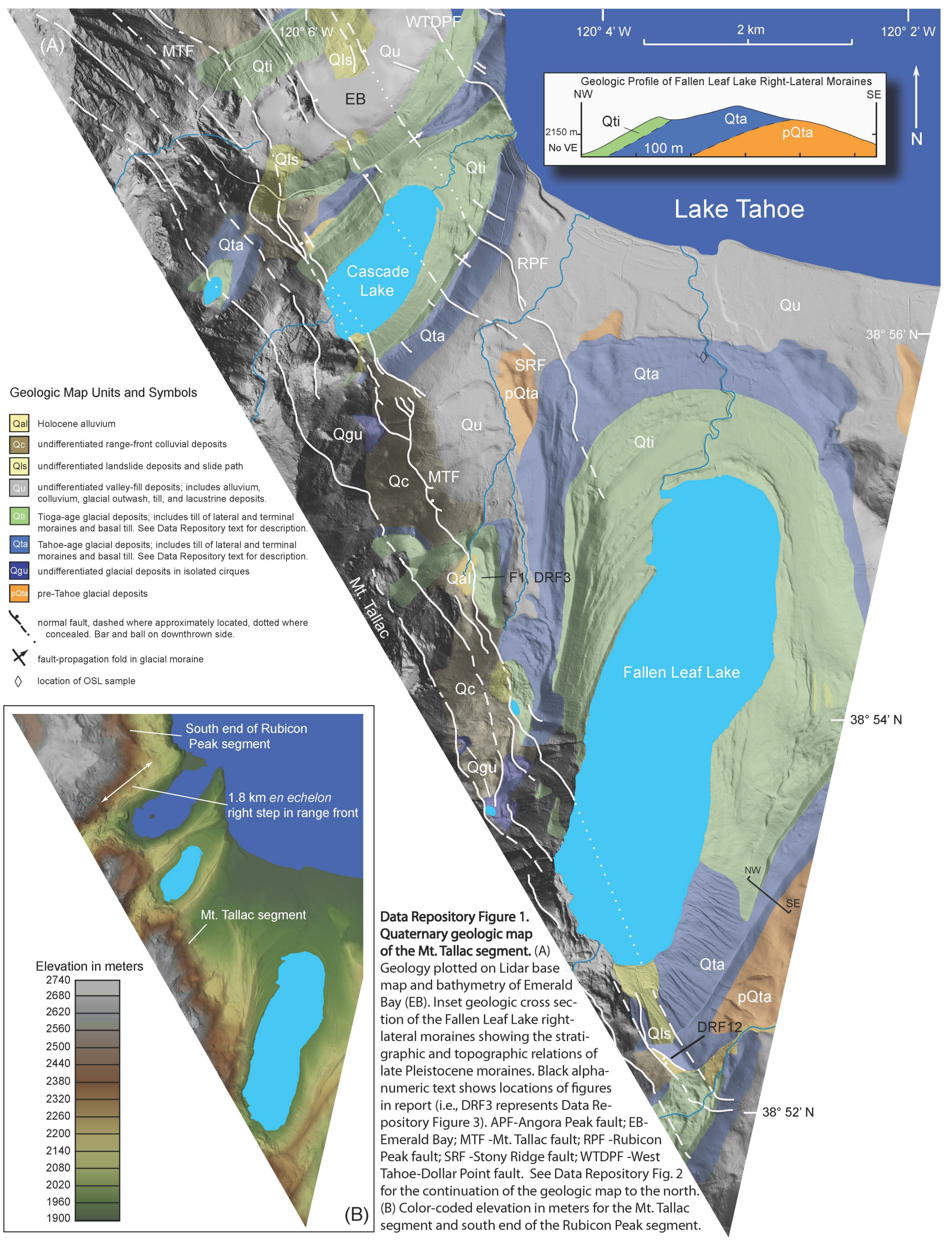




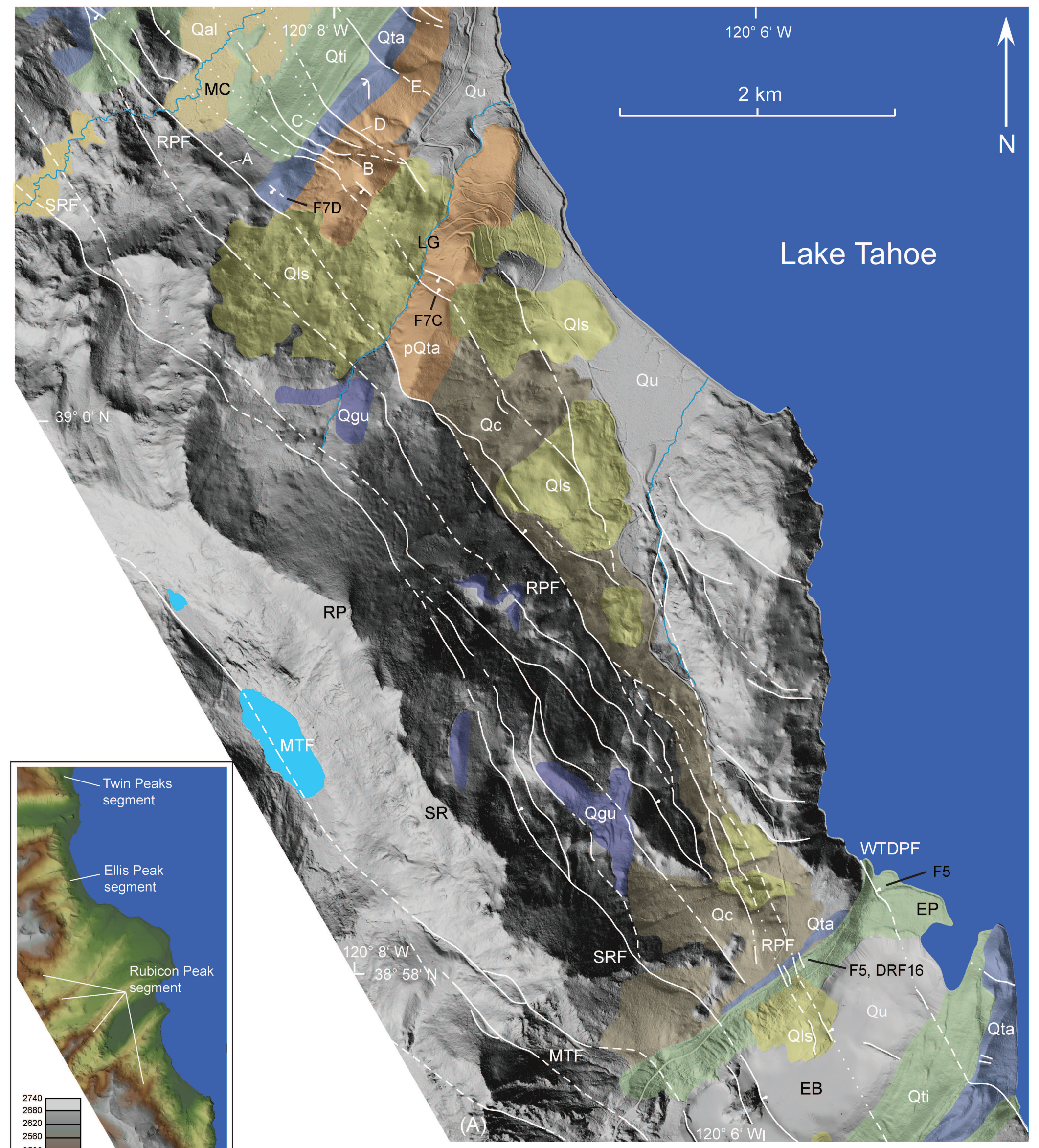

Data Repository Figure 2. Quaternary geologic map for the southern half of the Rubicon Peak segment. (A) Geology plotted on bare-earth LiDAR basemap and multibeam bathymetry of Emerald Bay (EB). EP - Emerald Point; LG - Loney Gulch; MC - Meeks Creek; MTF - Mt. Tallac fault; RP - Rubicon Peak; RPF - Rubicon Peak fault; SR - Stony Ridge; SRF - Stony Ridge fault; WTDPF West Tahoe-Dollar Point fault. See Figure DR1 for geologic map legend. White letters (A, B, C, D, and E) identify principal fault strands of the Rubicon Peak segment discussed in text. Black alphanumeric text shows locations of figures in report (i.e., F7C represents Figure 7C). (B) Inset showing color-coded elevation in meters for the Rubicon Peak and Ellis Peak segments. 


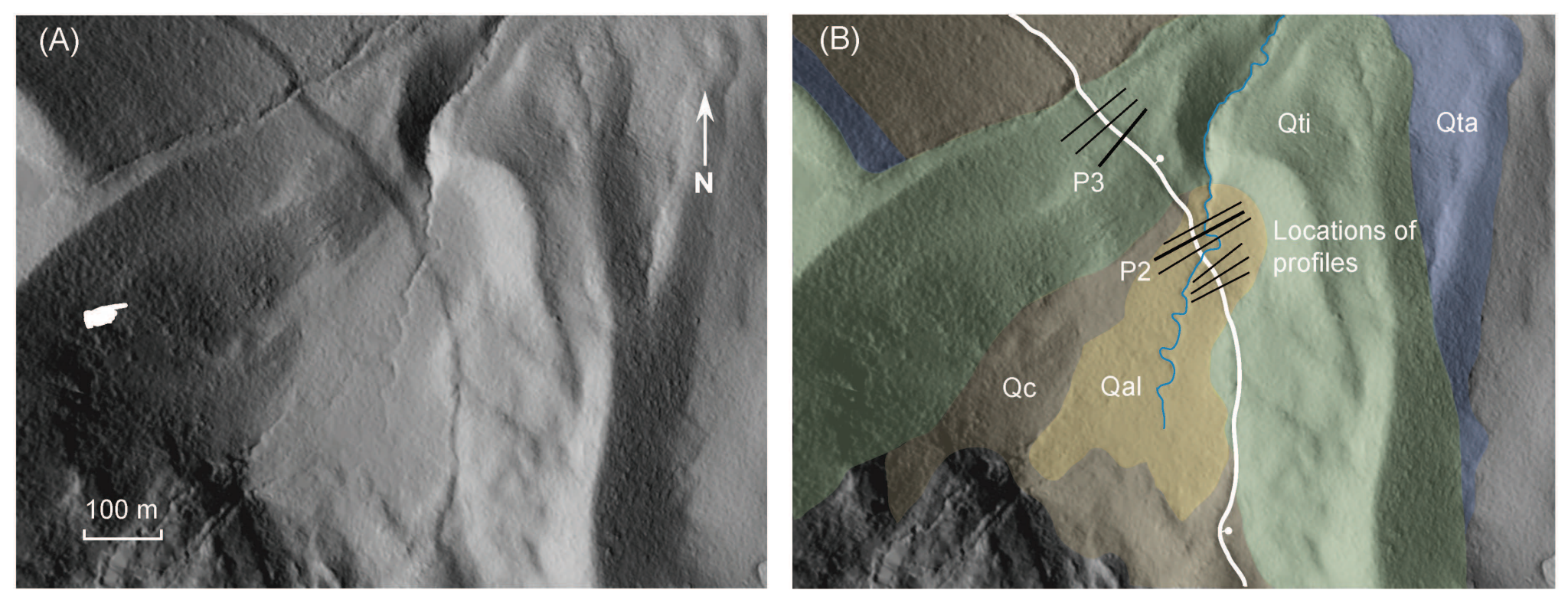

(C)
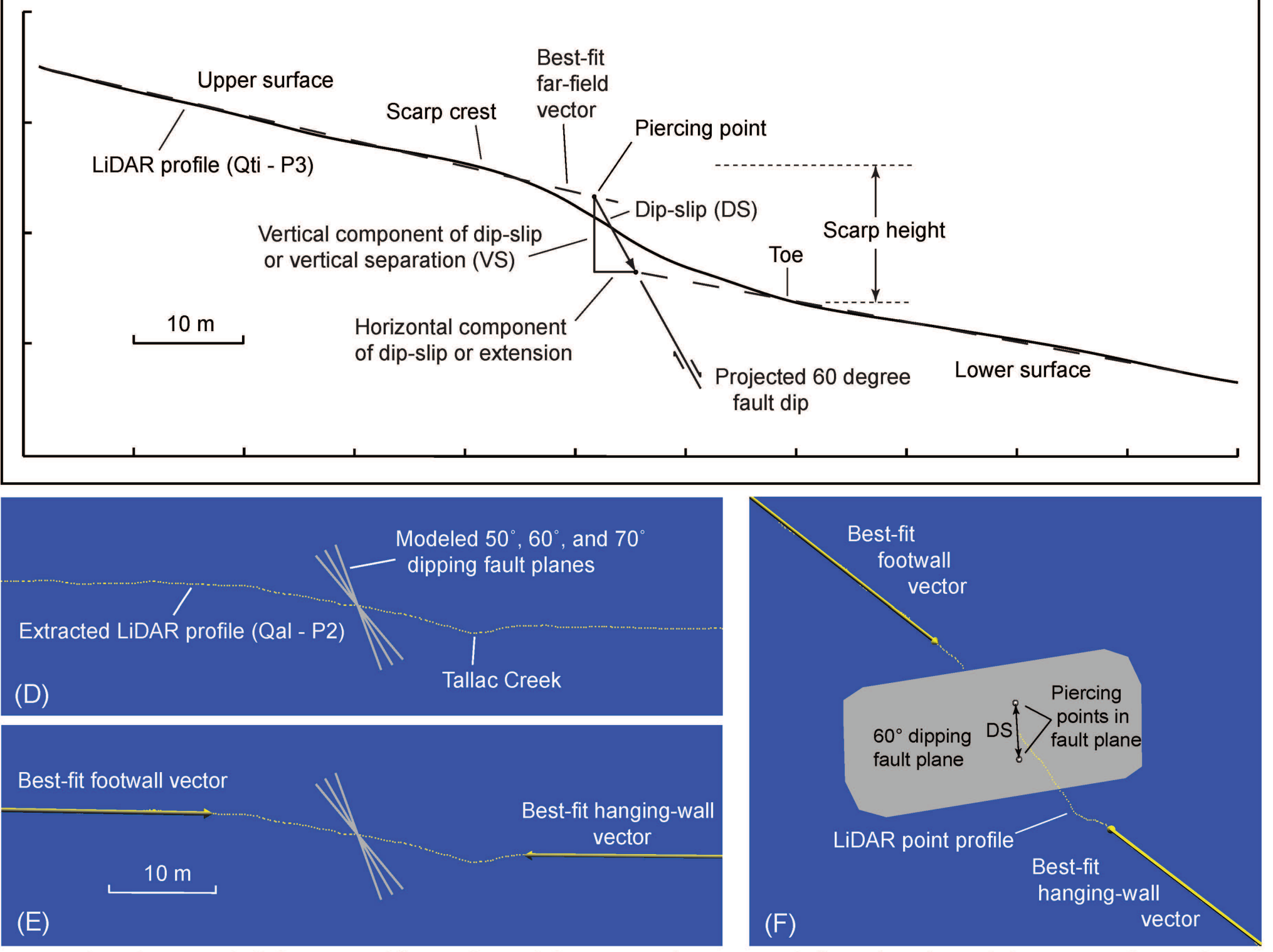

Data Repository Figure 3. Fault displacement modeling at Tallac Creek site. (A) Bare-earth LiDAR image of Tallac Creek site showing fault scarp on Mt. Tallac rangefront fault. Hand icon shows illumination angle. Vertical exaggeration is 1.5. (B) Quaternary geologic map of Tallac Creek site showing locations of LiDAR profiles discussed in text and shown in (C) and (D). Qal, Post-Tioga alluvium; Qti, Tioga moraine; Qta, Tahoe moraine; Qc, undifferentiated colluvium; solid white line is Mt. Tallac fault; bar and ball on downthrown side. (C) Profile extracted from LiDAR data (Qti - P3) with fault-scarp nomenclature and principal slip components for normal faults after Slemmons, (1957); Bursik and Sieh, (1989); and McCalpin, (1996). Note that scarp height exceeds vertical separation due to slope of offset moraine. (D) Points of profile extracted from LiDAR (Qal - P2) showing mid-scarp position of modeled 50,60, and 70 degree-dipping fault planes and fluvial channel of Tallac Creek at base of fault scarp. (E) Same profile with best-fit footwall and hanging-wall vectors. Note that in this case the scarp height is greater than the vertical separation due to the presence of the fluvial channel; otherwise, scarp height would equal vertical separation because the offset alluvium is horizontal. (F) Oblique view of same profile, showing the coupled set of piercing points defined by the intersection of the footwall and hanging-wall vectors with the 60 -degree-dipping fault plane. The vector between the piercing points in the fault plane is the dip-slip (DS) component. 

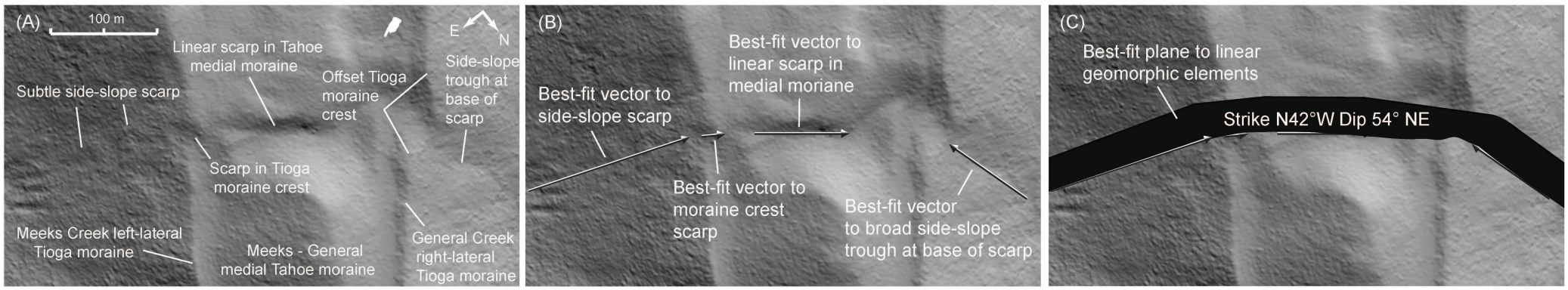

Data Repository Figure 4. Three-dimensional modeling of a fault plane using fault-controlled geomorphic features. We illustrate our new 3D modeling technique to approximate the orientation of fault planes at the medial moraine complex between Peeks Creek and General Creek. At this location, the linear Tioga maximum moraine crests on both sides of the complex are abruptly offset across fault $C$ and the crest segments are separated by scarps (see Figure DR5 for geologic map and location). Between the offset Tioga moraine crests, fault $C$ forms a broad, linear scarp in the topographically lower Tahoe moraine in the core of the medial complex. (A) Plan view bare-earth LiDAR image of medial moraine complex between Meets and General Creeks showing fault-controlled geomorphic features. Hand icon shows illumination direction. No vertical exaggeration. (B) Fault-controlled sideslope troughs are aligned with moraine crest scarps on both sides of the medial moraine complex. LiDAR ground points along trend of linear geomorphic features are identified in an interactive 3D environment and vectors are mathematically fit to the points. (C) The linear scarps and side-slope troughs are used to approximate the orientation of the fault by fitting a plane to the faultcontrolled geomorphic elements with a linear regression. In this example, the modeled fault plane dips $54^{\circ}$ northeast. At scarps elsewhere along the Rubicon Peak segment, we have approximated the orientations of fault planes in the same manner wherever the morphology permits. The average modeled fault dip is $62 \pm 12^{\circ}(n=7)$. 


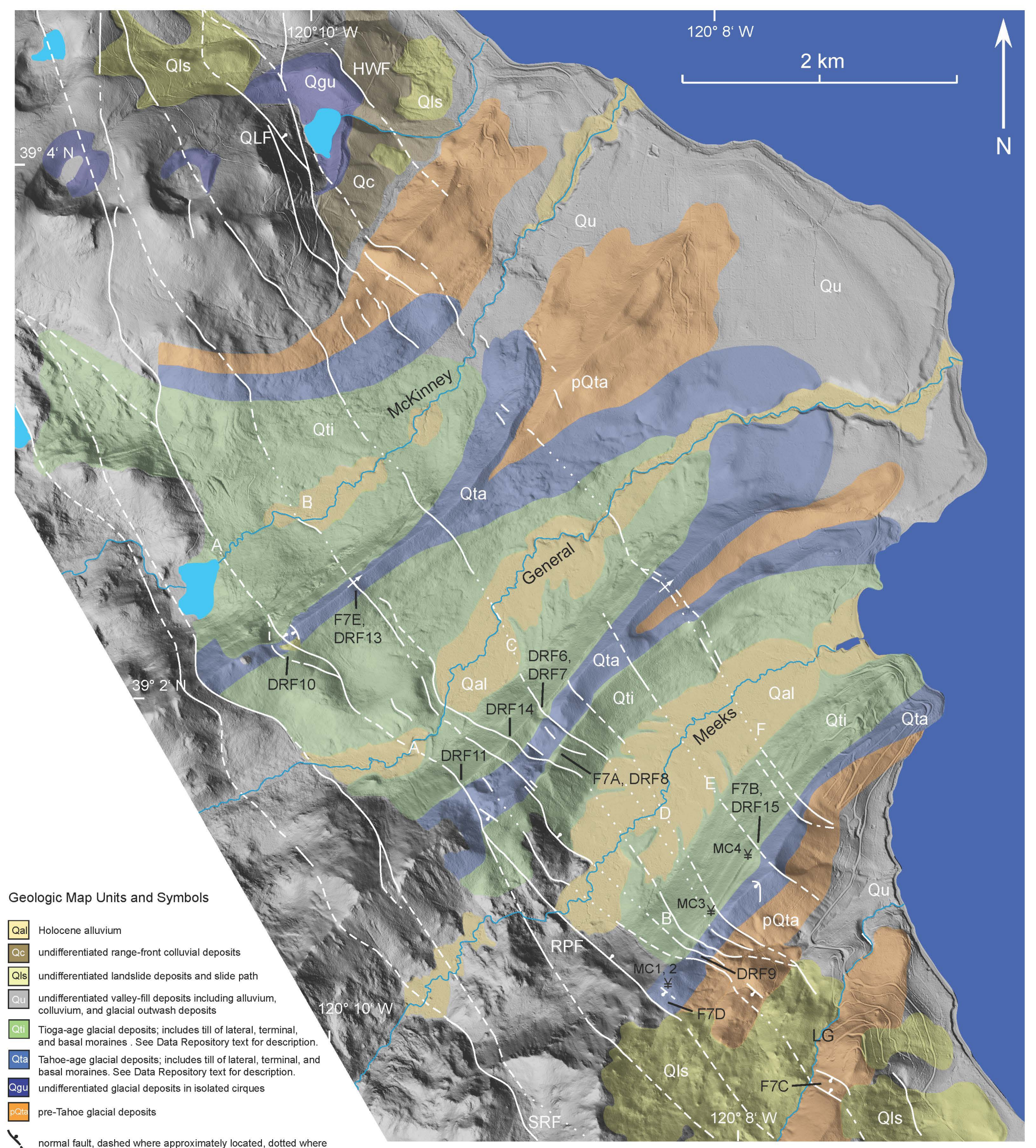

normal fault, dashed where approximately located, dotted where concealed. Bar and ball on downthrown side.

fault-propagation fold in glacial moraine

\# location of TCN sample and identifier

Data Repository Figure 5. Quaternary geologic map for the northern half of the Rubicon Peak segment. Quaternary geology plotted on bare-earth LiDAR base map. White letters (A, B, C, D, E and F) identify principal fault strands of the Rubicon Peak segment discussed in text. Black alpha-numeric text shows locations of figures in article and data repository text (i.e., DRF10 represents Data Repository Figure 10). HWFHomewood fault; LG - Lonely Gulch; QLF - Quail Lake fault; RPF - Rubicon Peak fault; SRF - Stony Ridge fault. See Figure DR2 for color-coded elevation map. 

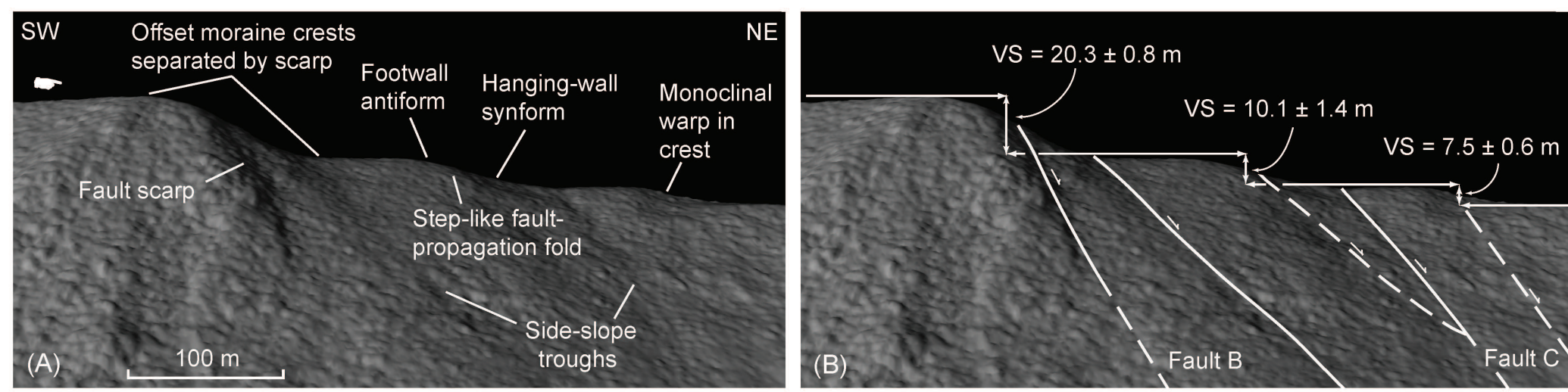

Data Repository Figure 8. Offsets in Meeks Creek left-lateral Tioga moraine at faults B and C. (A) Horizontal perspective looking northwest at fault-bounded steps in Tioga moraine crest, fault-controlled geomorphic features, and the right to left progression in deformation of a moraine crest where there is a thick section of unconsolidated glacial till above blind bedrock faults at depth. See text for discussion. Hand icon shows low-angle illumination direction accentuating side-slope features. View is roughly parallel to fault strike. (B) Same views as (A), showing fault traces and vertical separation (VS) derived from 3D models. Faults dashed where approximately located. See Fig. DR5 for geologic map and locations of faults B and C. 


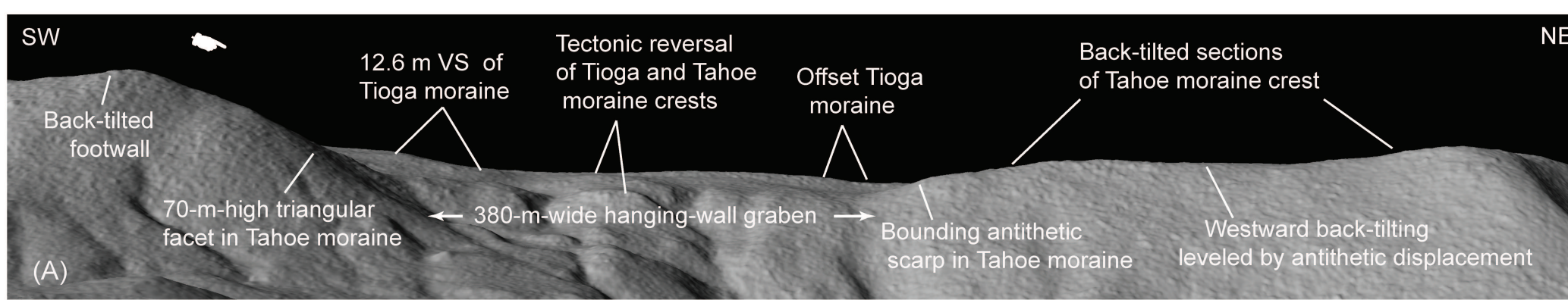

Footwall high point $2197 \mathrm{~m}$
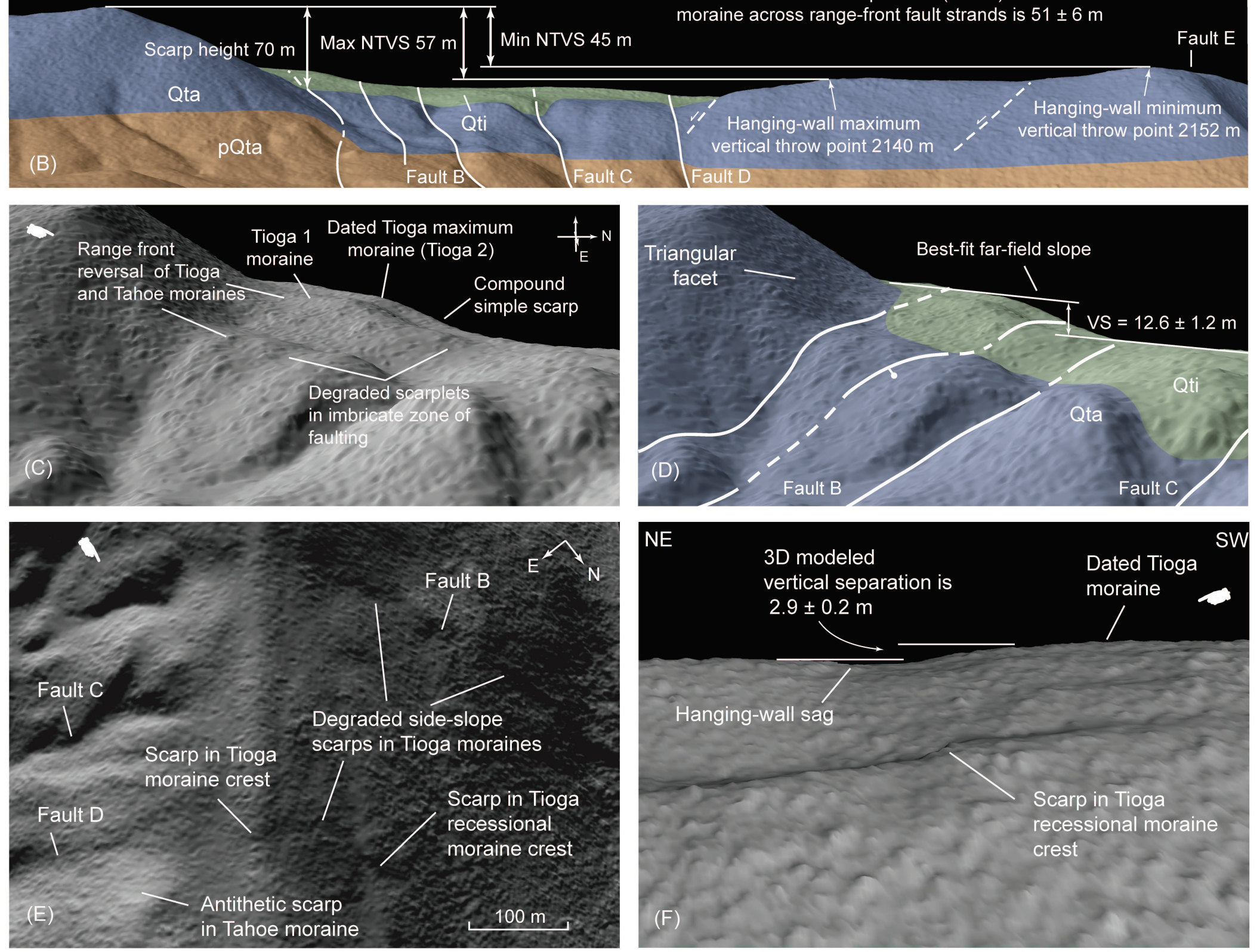

Data Repository Figure 9. Range front offsets of Tahoe and Tioga moraines at Meeks Creek right-lateral moraine complex. (A) Horizontal perspective looking northwest, parallel to fault strike, at south side of Meeks Creek moraine complex, showing range-front tectonic geomorphology discussed in text. Hand icon shows illumination direction. Vertical exaggeration (VE) is 1.25 . Width of image is approximately $1.25 \mathrm{~km}$. (B) Geologic profile with glacial units, faults, and strain markers in Tahoe moraine used to estimate net tectonic vertical separation (NTVS) across the width of the hanging-wall graben. Qti, Tioga moraine; Qta, Tahoe moraine; pOta, pre-Tahoe glacial deposits. Contacts are approximate. Faults are dashed where approximately located. See Fig. DR5 for geologic map. (C) Oblique view to the west, showing imbricate fault $B$ at the base of 70-m-high triangular facet shown in (A). VE is 1.5. (D) Oblique view with glacial units, fault strands, and vertical separation (VS) determined from moraine-crest-reconstruction and vector-fit modeling techniques. (E) Plan view image with low-angle illumination showing degraded side-slope scarps on north side of Meeks Creek moraine complex, along strike of faults B and D. VE is 1.75. (F) Horizontal perspective looking southeast at scarps in Tioga moraines on north side of moraine complex along fault $D$ and vertical separation in Tioga maximum moraine determined from 3D models. VE is 1.75 . Width of image is $\sim 200 \mathrm{~m}$. 


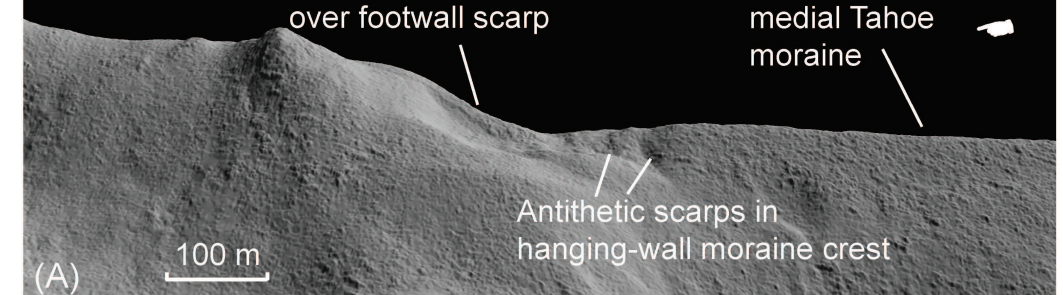

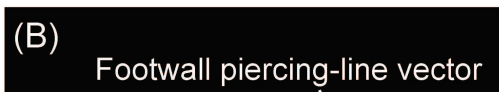

\section{Qta} Qti
3D modeled vertical separation (VS) is $44.2 \pm 1.0 \mathrm{~m}$
Footwall and hanging-wall piercing-liné vectors modeled with moraine-crestreconstruction and vector-fit techniques

Data Repository Figure 10. Range-front offset of McKinney - General Creek medial Tahoe moraine. (A) View looking northwest at south side of the medial moraine complex showing the range-front tectonic geomorphology discussed in text. Hand icon shows illumination direction. Vertical exaggeration is 1.5 . Width of image is approximately $1.1 \mathrm{~km}$.

(B) Same view as (A), showing Quaternary units, faults, and constructed footwall and hanging-wall piercing line vectors used to delimit vertical separation across the range-front fault. Qti, Tioga moraine; Qta, Tahoe moraine; Qls, landslide deposit. Barbed arrow on downthrown side of fault. Contacts are approximate; see Fig. DR5 for geologic map and location of range-front fault $A$. 


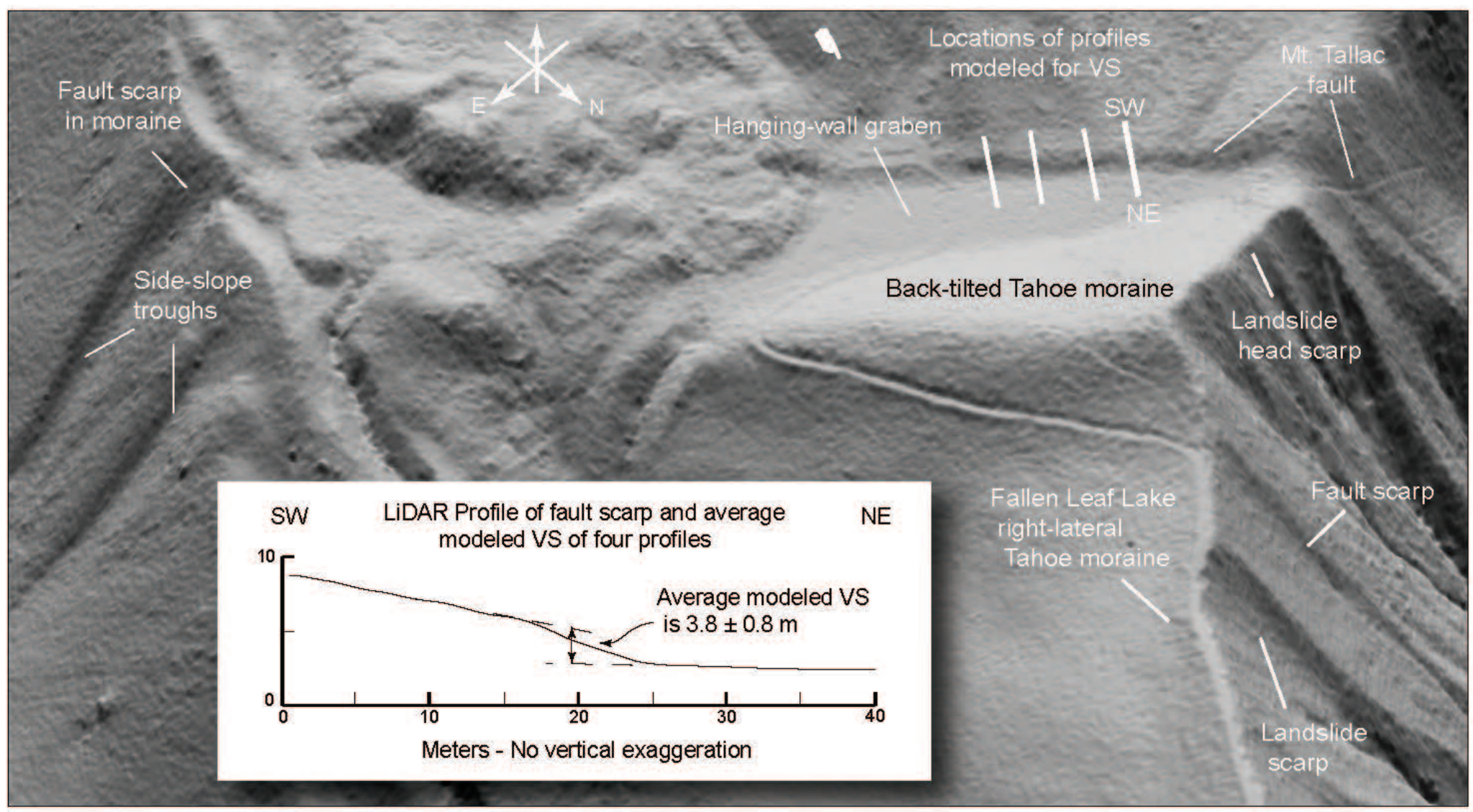

Data Repository Figure 12. South end of Mt. Tallac fault. Oblique bare-earth LiDAR image of south end of Mt. Tallac fault south of Fallen Leaf Lake and related tectonic geomorphic features discussed in text. View is to the southwest. See Fig. DR1 for geologic map and location. Inset LiDAR profile of fault scarp in colluvium and average modeled vertical separation (VS). See Mt. Tallac segment for description of modeling methods. 
SW McKinney - General medial

Tahoe moraine

Footwall antiform

/ Hanging-wall synform

Smooth, linear, and evenly graded

moraine crests on both sides of

extensional fault-propagation fold

above blind bedrock fault at depth

(A) $100 \mathrm{~m}$

Best-fit far-field piercing-line vector

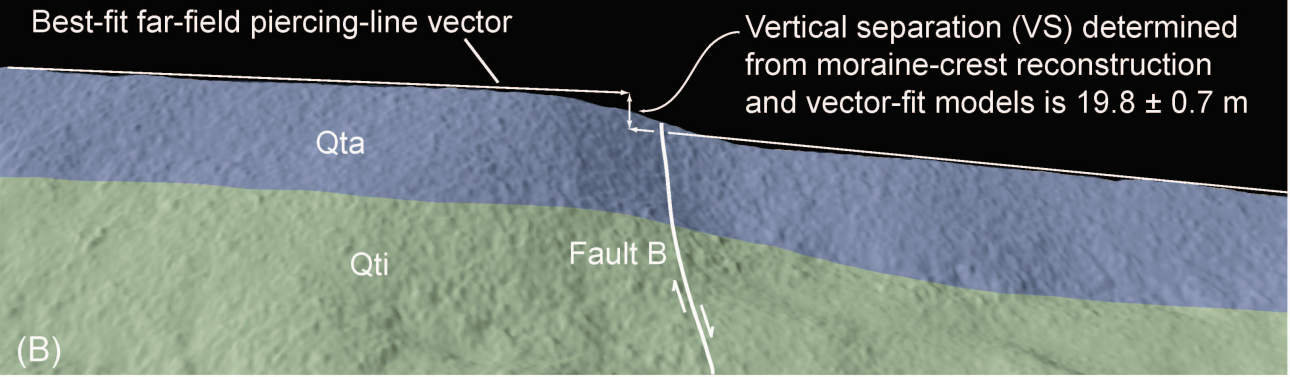

NE

Data Repository Figure 13. Fault propagatron fold in McKinney - General Creek medial Tahoe moraine. (A) Horizontal perspective looking northwest at extensional fault-propagation fold in medial Tahoe moraine, showing geomorphic features discussed in text. General Creek left-lateral Toga moraine is in foreground. Hand icon shows illumination direction. Vertical exaggeration is 1.5 . Width of image is approximately $0.85 \mathrm{~km}$. (B) Same view as (A), showing glacial units, fault $B$, best-fit far-field piercing line vectors, and vertical separation determined from 3D models. Qta, Tahoe momaine; Qti, Tioga moraine. See Fig. DR5 for geologic map and location of fault $B$. 


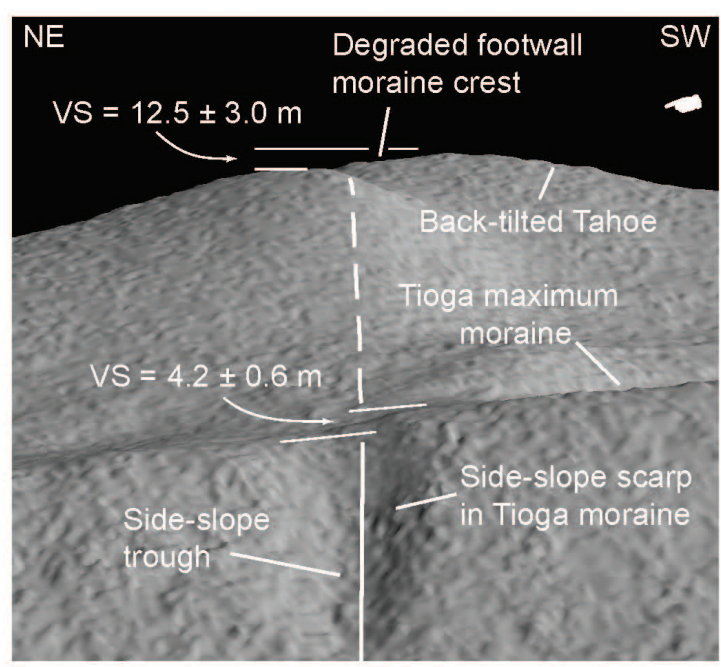

Data Repository Figure 15. Vertical separation in Meeks Creek rightlateral Tahoe and Tioga moraines along fault E. Fault-parallel view to the southeast, showing opposite slopes of Tahoe moraine crest on both sides of fault $E$ as discussed in data repository text, tectonic geomorphic features, and vertical separations (VS) in Tahoe and Tioga moraine crests determined from 3D modeling. Hand icon shows illumination direction. Distance along Tioga maximum moraine crest is $\sim 200 \mathrm{~m}$. See Fig. DR5 for geologic map and location. Vertical exaggeration is 1.3. 

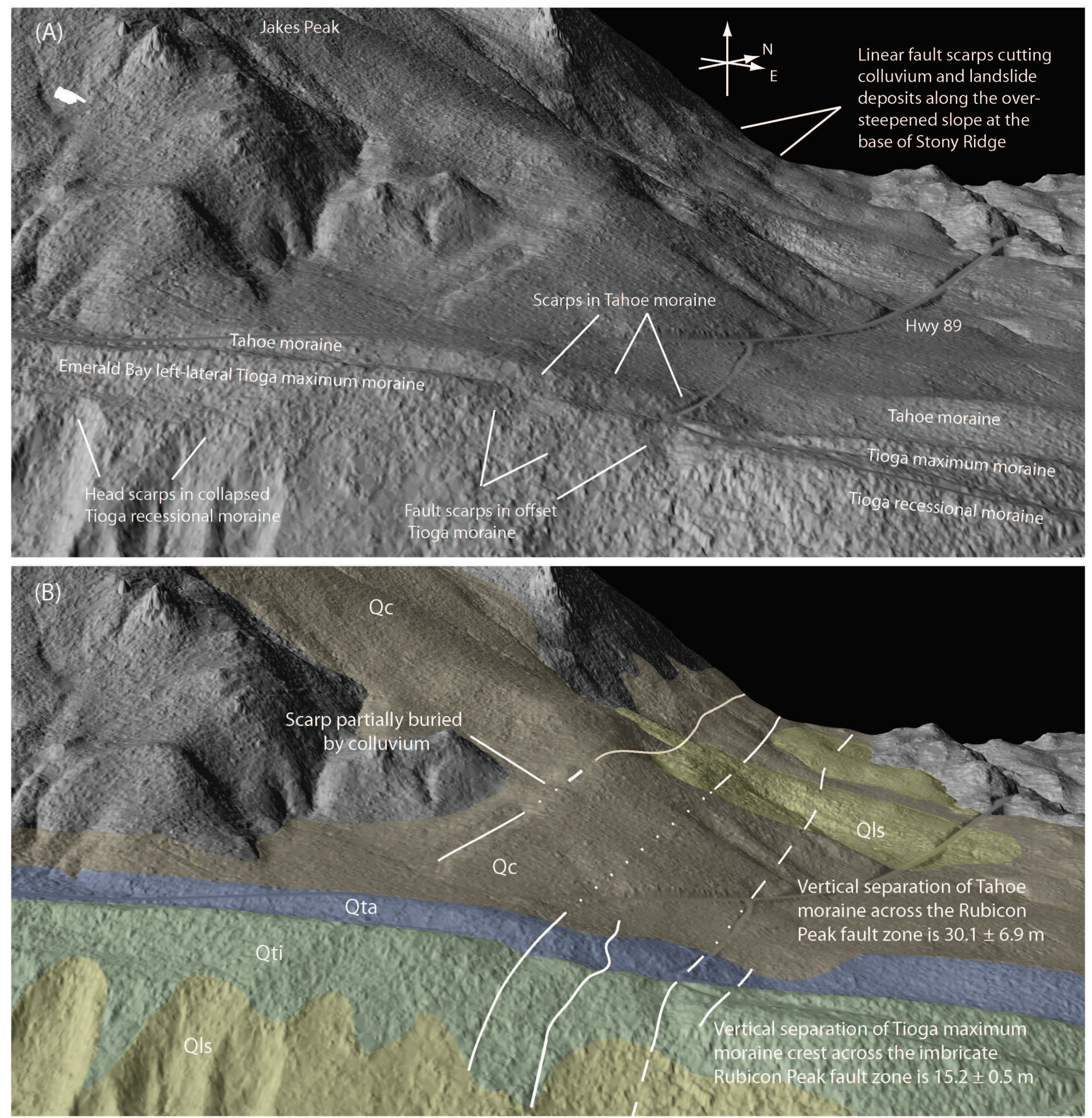

Data Repository Figure 16. Offsets of Tahoe and Tioga moraines at Emerald Bay left-lateral moraine complex.

(A) Oblique perspective looking northwest, along fault strike, at south side of Emerald Bay left-lateral moraine complex, showing linear range-front fault scarps, scarps in Tioga and Tahoe moraines, and selected geographic features. Hand icon shows illumination direction. Vertical separation is 1.5. Horizontal distance along Tioga maximum moraine is approximately $900 \mathrm{~m}$. (B) Same view as (A), with Quaternary units, faults, and vertical separation of Tioga and Tahoe moraines modeled with moraine-crest-reconstruction and vector-fit techniques. Qti, Tioga moraine; Qta, Tahoe moraine; QIs, landslide paths and deposits; Qc, colluvium. Contacts are approximate. Faults are dashed where approximately located, dotted where concealed. See Fig. DR2 for geologic map. 